\title{
TO THE $100^{\mathrm{TH}}$ ANNIVERSARY OF THE PERM STATE UNIVERSITY
}

UDC 338.24:332.1

LBC 65.050+65.04

\section{COMPETITIVENESS AND MANAGEMENT OF THE NATIONAL AND REGIONAL ECONOMY'S DEVELOPMENT: SYNTHESIS OF HIERARCHICAL AND INSTITUTIONAL ANALYSIS}

\author{
Elena V. Bazueva, Candidate of Economic Sciences, Associate Professor \\ E-mail: bazueva.l@mail.ru \\ Perm State University; 15, Bukireva st., Perm, 614990, Russia
}

Eugene E. Zhulanov, Candidate of Economic Sciences, Associate Professor

E-mail: zeepstu@yandex.ru

Perm National Research Polytechnic University; 29, Komsomolsky prospekt, Perm, 614990, Russia

Tatyana V. Karlina, Candidate of Economic Sciences, Associate Professor

E-mail: tkarlina@yandex.ru

Perm State University; 15, Bukireva st., Perm, 614990, Russia

Tatyana Yu. Kovaleva, Candidate of Economic Sciences, Associate Professor

E-mail: kovalevatu@yandex.ru

Perm State University; 15, Bukireva st., Perm, 614990, Russia

Tatyana V. Mirolyubova, Doctor of Economic Sciences, Professor, Head of the Department of Global and Regional Economy, Economic Theory, Dean of the Faculty of Economics

E-mail: mirolubov@list.ru

Perm State University; 15, Bukireva st., Perm, 614990, Russia

Dmitriy N. Shults, Candidate of Economic Sciences, Associate Professor

E-mail: shultz@prognoz.ru

Perm State University; 15, Bukireva st., Perm, 614990, Russia

The paper gives a review of theoretical, methodological and applied conclusions and results obtained by the academic school "Competitiveness and management of socio-economic systems development: synthesis of hierarchical and institutional modeling of socio-economic systems”. The school was founded by Professor Yu.K. Persky. The research conducted by academic economists from Perm is focused on the problems of interlevel analysis of socioeconomic systems on the basis of the hierarchical and institutional approaches. The instrumentarium suggested proves that hierarchical and institutional interrelations, being ignored by traditional neoclassical theory, should be thoroughly studied. It also emphasizes the necessity for system research into the problem of competitiveness and management in terms of the economic hierarchy: at nano, mini, micro, meta, meso, macro and mega levels. The key elements that research within the framework of the academic school focuses on are the following: an integral model of hierarchal economy taking into account interlevel interaction and institutional structuring; modeling of direct, reverse, vertical and horizontal interrelations, their typology and evaluation of their influence at different hierarchy levels; improvement of the state economic policy; issues of asymmetric distribution and circulation of information flows and their optimization; the problem of harmonization of economic relations participants' interests and etc. Special attention is given to regional studies of Perm scientists, devoted to theory, methodology and practical aspects of the regional economy's development with the aim of improving economic policy of the region. In particular, the results of identification and evaluation of clusters in the region's economy are given, the urgent necessity of forming an integral model of the territory's cluster spatial development is justified. Moreover, the article suggests directions of developing a competitive innovative system in the region and shows the opportunities of strategic management processes modeling and implementation of effective international economic activity and development of market infrastructure for regional economy. Thus, the synthesis of hierarchical and institutional analysis made it possible to develop methodical and methodological basis for the research into hierarchically organized national and regional economies, separate enterprises, industrial branches and technological complexes as well as to work out models of markets for goods and resources and to structure and design different institutional systems and socio-economic processes.

Keywords: hierarchical approach, institutional approach, interlevel analysis, institutions, socio-economic systems, competitiveness, management, efficiency, national economy, regional economy, innovations, cluster. 


\section{Introduction}

Over the past fifteen years, scientists of the Faculty of Economics of Perm State National Research University together with those from Perm National Research Polytechnic University have been investigating the problem of structural transformation of socioeconomic systems and its interaction with social and scientific progress.

The study of these transformations requires a complex and integral approach, which would allow one to reveal multifold regularities in the development of markets, branches, economic complexes, territories, enterprises and organizations, industrial systems and management processes. Looking at the problem of structural transformations at the above angle can definitely be a self-contained subject of theoretical and applied analysis and needs corresponding definitions to be developed along with methodical and methodological insrtumentarium, which would help to perform the tasks of providing successful competitive development and steady growth of socio-economic systems experiencing dramatic qualitative changes.

Due to the great number of researches conducted, Perm scientists obtained significant academic results helpful for the development of methods and models of the institutional hierarchical analysis of socio-economic systems in the context of competitive market and innovative transformation of national economy and territories. The general trend and the most important achievements of these researches are associated with representatives of the academic school “Competitiveness and management of socioeconomic systems development: synthesis of hierarchical and institutional modeling of socio-economic systems", whose founder was Doctor of Economic Sciences, Professor, Honored Worker of Higher Education of the Russian Federation Yuri Persky (19362015).

Yu.K. Persky laid fundamental theoretical principles and developed methodological instrumentarium which provide the unity of synthetic description of integral economic hierarchy and study of interlevel interaction problems. The idea of the hierarchical analysis and its consequent development is presented in the following major works $[25 ; 26 ; 76 ; 80 ; 83 ; 82 ; 89 ; 90$; $113]$ and articles [69; 70; 71; 75; 79; 87; 88].

In fact, the interlevel approach suggested by Yu.K. Persky performs the function of systematization in the research into socio-economic systems as a hierarchy of various levels (primarily micro-, meso- and macrolevels of economy's functioning). However, under the above approach the main problem is the influence of different elements of macroeconomic level on the performance of macroeconomic entities as well as the influence a set of macroeconomic entities has on formation of macroeconomic tendencies [25, p. 34]. The most important aspect of the research is the study of institutional peculiarities of socio-economic dynamics of interlevel interaction and interinfluence. The system is of polysrtuctural nature so it is potentially oriented to the responses of structural reformation competitive impulses; it includes an institutional element providing the possibility of intersystem transformation by means of constantly improving institutions (a set of formal and informal norms and rules as well as mechanisms of their enforcement). As a result, due to the synthesis of hierarchical and institutional modeling of socio-economic systems, Yu.K. Persky and his followers have been solving scientific applied tasks of competitive market and innovative modernization of national and regional economy as a whole along with more specific issues concerning development of entrepreneurship, innovations and investments, markets of goods and resources, improvement of manufacturing, financial, market processes taking place at enterprises as well as some state management tasks $[3 ; 17 ; 18 ; 37$; 74; 75; 77; 78; 79; 93; 84; 91].

The article presents the major results and achievements of the Perm academic school in the following areas.

1. Modeling of hierarchical socio-economic systems.

2. Study and modeling of reproductive interaction between territorial socio-economic systems.

3. Structuring and designing of the system of institutions: prospects of the hierarchical approach (through the example of the system of gender power institutions).

4. The hierarchical system of intellectual entrepreneurship institutions.

5. Study of the mechanism of regulating the system of regional goods markets on the basis of the hierarchical approach.

6. Approaches and applications of hierarchical and institutional analysis towards modeling of various socio-economic systems.

\section{Modeling of hierarchical socio-economic} systems

Hierarchical analysis of economy appeared in 2000 when the paper by Yu.K. Persky and L.V. Kostareva "Enterprise and Macroeconomic Environment (the Fundamentals of Mesoeconomics)" was published [82].

Unlike the neoclassical approach, considering a firm as a "black box" the newly introduced one suggested taking a firm as a system functioning surrounded by higher level systems. In this view a firm is a "microelement, a microenvironment of single market space” [82] (Fig. 1). 


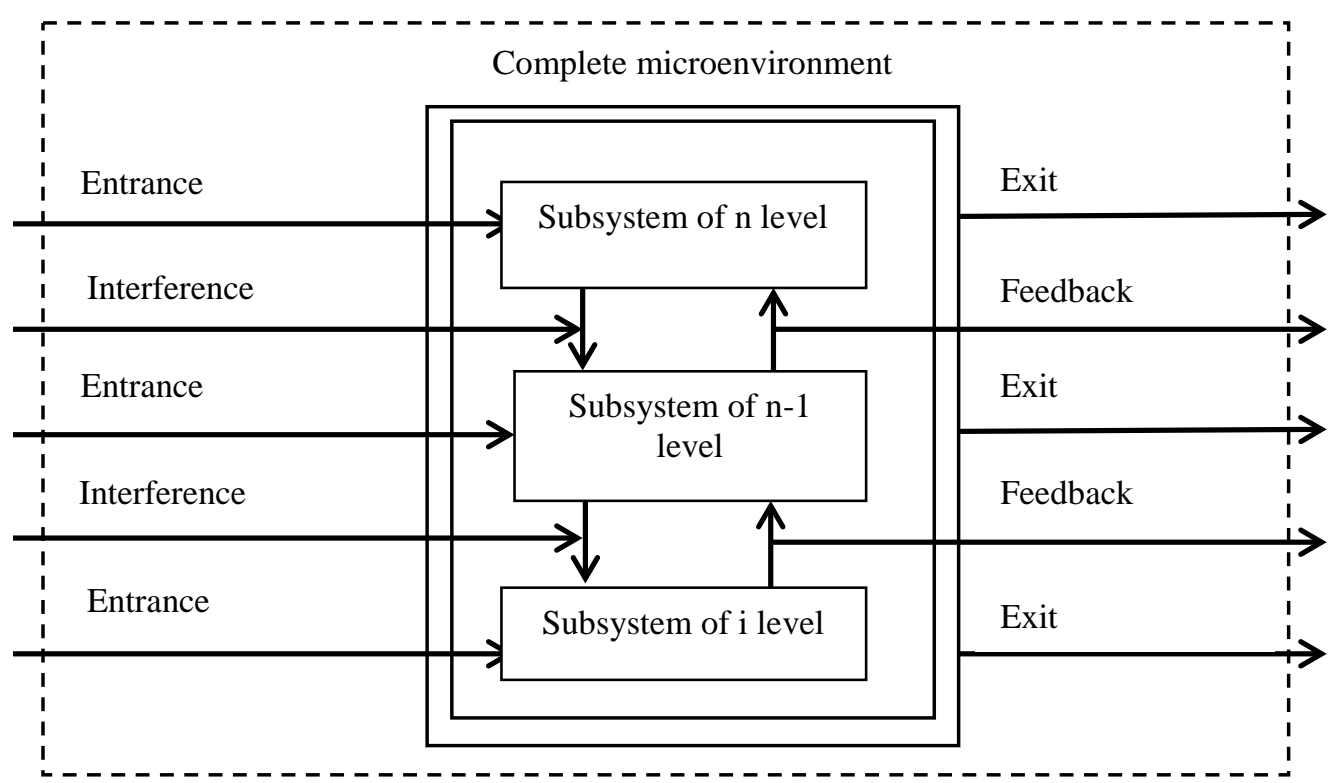

Fig. 1. An enterprise as a multilevel hierarchical system [82, p. 9]

In a hierarchical system a firm tends to achieve its own purposes when the external environment is changing, but at the macroeconomic level governmental authorities work out regulatory controls only following their own priorities. Thus, the problem arises "how to achieve the unity of interests of macro- and microlevels of economy” [82, p. 11]. Presentation of the problem in this way is aimed at overcoming a common methodological gap between neoclassical microeconomics and Keynesian macroeconomics, emerged in economic theory in the $20^{\text {th }}$ century.

The work mentioned above defined the subject of "mesoeconomic" analysis as "interinfluence (so called mutual reflection) of macro- and microeconomic processes, the nature of their interaction and interrelation" [82, p. 11]. The given approach to the mesoeconomics problems has become a special feature of the Perm school of hierarchical analysis.

In their work, Yu. Persky and L. Kostareva proposed the first model describing interaction between micro- and macrolevels of economy, which they named an "integrated model of functioning of the system "economic entities (microsystems)-macroeconomic environment” [82, p. 11]. The authors were first who managed to formally describe interrelations between micro- and macrolevels within the framework of the “matrix model of interlevel analysis" (Table 1).

Matrix model of interlevel analysis [82, p. 30]

\begin{tabular}{|c|c|c|c|c|c|c|c|c|c|c|}
\hline \multirow[b]{3}{*}{ Macrovariables } & \multicolumn{10}{|c|}{ Microvariables } \\
\hline & \multicolumn{2}{|c|}{$\begin{array}{l}\text { Income } \\
T R=Q P\end{array}$} & \multicolumn{3}{|c|}{$\begin{array}{c}\text { Capital expenses } \\
T C_{k}=K R+q K\end{array}$} & \multicolumn{2}{|c|}{$\begin{array}{c}\text { Labor expenses } \\
T C_{L}=L W\end{array}$} & \multicolumn{2}{|c|}{$\begin{array}{c}\text { Tax expenses } \\
T=T_{p}+T_{n}\end{array}$} & \multirow{2}{*}{$\begin{array}{l}\text { Profit } \\
P_{i}=T R- \\
-T C_{k}- \\
T C_{L}-T\end{array}$} \\
\hline & $\begin{array}{c}\text { Output } \\
Q\end{array}$ & $\begin{array}{c}\text { Price } \\
P\end{array}$ & $\begin{array}{c}\text { Capital } \\
\qquad K\end{array}$ & $\begin{array}{l}\text { Expens- } \\
\text { es } R\end{array}$ & \begin{tabular}{|c|} 
Retire- \\
tire- \\
ment \\
$q K$
\end{tabular} & $\begin{array}{c}\text { Labor } \\
\qquad L\end{array}$ & $\begin{array}{c}\text { Wage } \\
W\end{array}$ & $\begin{array}{l}\text { Production } \\
\text { taxes } T_{n}\end{array}$ & $\begin{array}{c}\text { Personal } \\
\text { tax } \\
T_{n}\end{array}$ & \\
\hline $\begin{array}{l}\text { 1. Total product } \\
Y=C+I+G+N X\end{array}$ & $\begin{array}{l}Y=\Sigma Q_{m} \\
(+)\end{array}$ & $\overline{0}$ & $\begin{array}{c}F\left(K^{\alpha}, L^{1-\alpha}\right) \\
M P K=0\end{array}$ & $\begin{array}{c}R=q+n+ \\
g \\
M P K=R\end{array}$ & $M P K=q$ & $\begin{array}{c}F=\underset{\alpha}{\alpha}\left(K^{\alpha}, L 1^{-}\right. \\
(+)\end{array}$ & $\begin{array}{c}(+) \\
W=(Y- \\
T)\end{array}$ & $\begin{array}{c}\Delta Y=\Delta T_{n}(- \\
M P C / \\
(1-M P C)) \\
(-)\end{array}$ & $\begin{array}{c}\Delta Y= \\
=\Delta T_{n}(- \\
M P C / \\
(1-M P C)) \\
(-)\end{array}$ & $(+)$ \\
\hline $\begin{array}{l}\text { 2. Consumer ex- } \\
\text { penditures } \\
C=C(Y \cdot T)\end{array}$ & $\begin{array}{c}C=C\left(\Sigma Q_{m}\right) \\
(+)\end{array}$ & $\begin{array}{c}\Delta C \% \\
==E_{p} \\
\Delta P \% \\
(-)\end{array}$ & $\begin{array}{c}\text { max } C \\
\text { when } \\
M P K- \\
q=n+g \\
\Delta C \%=\gamma \\
(K \%+L \%) \\
(+)\end{array}$ & $\begin{array}{c}R=y-C \\
(-)\end{array}$ & $\begin{array}{c}\sigma k= \\
Y \cdot C \\
\text { when } \\
\Delta k=0 \\
(-)\end{array}$ & $\begin{array}{c}C=\Sigma c \\
L ? 100-n\end{array}$ & $\begin{array}{c}C= \\
\Sigma L W \\
(1-B) \\
(+)\end{array}$ & $\begin{array}{c}\Delta C= \\
=\Delta T_{n}(-M P C / \\
(1-M P C)) \\
(-)\end{array}$ & $\begin{array}{c}\Delta C= \\
=\Delta T_{p}(- \\
M P C / \\
(1-M P C)) \\
(-)\end{array}$ & $(+)$ \\
\hline $\begin{array}{l}\text { 3. Savings } \\
S_{n}=S_{p}+S_{g}= \\
S(Y \cdot T)\end{array}$ & $\begin{array}{c}S_{p}=S \Sigma Q_{m} \\
\Sigma Q_{m}=F\left(S_{g}\right) \\
(+)\end{array}$ & $(-)$ & $\begin{array}{c}\Delta k= \\
\Delta s(M P K(1- \\
-M P K) \\
(+)\end{array}$ & $\begin{array}{c}R=s y \\
(+)\end{array}$ & $\begin{array}{c}\sigma k=s y \\
\text { when } \\
\Delta k=0 \\
(+)\end{array}$ & $\begin{array}{c}S=\Sigma S y \\
\text { when D } \\
100-\mathrm{T}\end{array}$ & $\begin{array}{c}S=\Sigma L_{W S} \\
(+)\end{array}$ & $\begin{array}{c}\Delta S=\Delta T_{n}(- \\
M P C / \\
(1-M P C)) \\
(-)\end{array}$ & $\begin{array}{c}\Delta S= \\
=\Delta T_{p}(- \\
M P C / \\
(1-M P C)) \\
(-)\end{array}$ & $(+)$ \\
\hline $\begin{array}{l}\text { 4. Investments } I= \\
S_{n}=I+\sigma K\end{array}$ & $\begin{array}{c}\Delta \Sigma Q_{m}= \\
=\Delta I /(1- \\
M P C) \\
(+)\end{array}$ & 0 & $\begin{array}{c}\Delta k=i-\sigma k \\
(+)\end{array}$ & $\begin{array}{c}R=I \\
(+)\end{array}$ & $\begin{array}{c}i=\sigma k \\
(+)\end{array}$ & $\begin{array}{c}I=\Sigma S y \\
L ? 100-n \\
\quad(+)\end{array}$ & $\begin{array}{c}I=\Sigma L_{W S} \\
(+)\end{array}$ & $\begin{array}{c}\Delta I=\Delta T_{b}(- \\
M P C / \\
(1-M P C)) \\
(-)\end{array}$ & $\begin{array}{c}\Delta I= \\
=\Delta T_{p}(- \\
M P C / \\
(1-M P C)) \\
(-)\end{array}$ & $(+)$ \\
\hline
\end{tabular}


E.V. Bazueva, E.E. Zhulanov, T.V. Karlina, T.Yu. Kovaleva, T.V. Mirolyubova, D.N. Shults

\begin{tabular}{|c|c|c|c|c|c|c|c|c|c|c|}
\hline \multirow[b]{4}{*}{ Macrovariables } & \multirow{2}{*}{\multicolumn{10}{|c|}{ Microvariables }} \\
\hline & & & & & & & & & & \\
\hline & \multicolumn{2}{|c|}{$\begin{array}{c}\text { Income } \\
T R=Q P\end{array}$} & \multicolumn{3}{|c|}{$\begin{array}{l}\text { Capital expenses } \\
T C_{k}=K R+q K\end{array}$} & \multicolumn{2}{|c|}{$\begin{array}{c}\text { Labor expenses } \\
T C_{L}=L W \\
\end{array}$} & \multicolumn{2}{|c|}{$\begin{array}{c}\text { Tax expenses } \\
T=T_{p}+T_{n}\end{array}$} & \multirow{2}{*}{$\begin{array}{l}\text { Profit } \\
P_{i}=T R- \\
-T C_{k}- \\
T C_{L}-T\end{array}$} \\
\hline & $\begin{array}{l}\text { Output } \\
Q\end{array}$ & $\begin{array}{c}\text { Price } \\
P\end{array}$ & $\begin{array}{l}\text { Capital } \\
\quad K\end{array}$ & $\begin{array}{l}\text { Expens- } \\
\text { es } R\end{array}$ & $\begin{array}{c}\text { Retire- } \\
\text { tire- } \\
\text { ment } \\
q K\end{array}$ & $\begin{array}{l}\text { Labor } \\
\quad L\end{array}$ & $\begin{array}{l}\text { Wage } \\
W\end{array}$ & $\begin{array}{l}\text { Production } \\
\text { taxes } T_{n}\end{array}$ & $\begin{array}{c}\text { Personal } \\
\operatorname{tax} \\
T_{n}\end{array}$ & \\
\hline $\begin{array}{l}\text { 5. Government } \\
\text { expenditures } \\
(T-G) ; \\
\Delta Y / \Delta G=1 /(1- \\
M P C)\end{array}$ & $\begin{array}{c}\Delta G_{m}= \\
=M C \Delta Q_{m} \\
(+)\end{array}$ & $(+)$ & - & - & - & - & - & - & - & $(+)$ \\
\hline 6. Taxes $T=T_{p}+T_{b}$ & $\begin{array}{c}\Delta Q_{m}= \\
=\Delta T(-M P C / \\
(1-M P C)) \\
(-)\end{array}$ & $(+)$ & - & - & - & - & - & $\begin{aligned} T_{b}=T+t Q_{m} \\
(+)\end{aligned}$ & $\begin{aligned} T_{p}= & T+t W_{m} \\
& (+)\end{aligned}$ & $(-)$ \\
\hline $\begin{array}{l}\text { 7. Money circula- } \\
\text { tion } M V=P Y\end{array}$ & $M V / P=\Sigma Q_{m}$ & $\begin{array}{c}M V / \\
\Sigma Q_{m}= \\
P\end{array}$ & - & $\begin{array}{c}R= \\
= \\
M V / \Sigma Q_{m}\end{array}$ & - & - & $\begin{array}{c}w= \\
=T+ \\
t Q_{m}\end{array}$ & - & - & $(-)$ \\
\hline 8. Interest rates & $(-)$ & $(+)$ & $(-)$ & $(+)$ & & & $(+)$ & & & $(-)$ \\
\hline
\end{tabular}

The matrix model was developed in later publications of Yu. Persky and D. Shults [89; 90]. For instance, they offered to differentiate between downward and upward interlevel links. The simplest double-level economic model is presented in Fig. 2, where $A$ is an operator of direct upward links between microvariables $x$ and macrovariables $y, B$ is an operator of direct downward links between microvariables $x$ and macrovariables $y, z$ is an entering vector, which is exogenous in relation to the economic system.

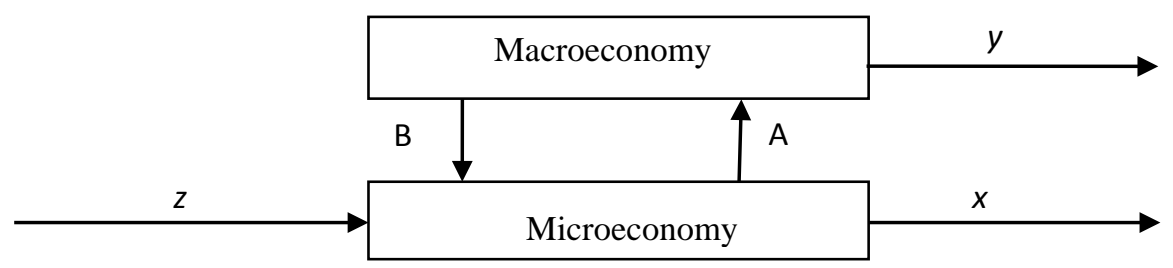

Fig. 2. An enterprise as a multilevel hierarchical system

In this model it is the expression (I-BA) ${ }^{-1} \mathrm{~A}$ but not the operator $A$ that determines the final influence (with the account of indirect upward and downward links) of any microeconomic shocks on the macroeconomic level. Similarly, the effect from regulating influences of macroeconomic level is not just $\mathrm{B}$, but the operator $B(I-B A)^{-1}$.

Thus, complex modeling of the interaction between micro- and macrolevels of economy allows governmental authorities to develop more effective economic policy as well as makes it possible for enterprises to take more effective management decisions.

Moreover, in the course of the research it was found that there is an asymmetry of upward and downward links. The former can be described as "from many to one" relationships while the latter can represent the type "from one to many". As a result, upward and downward links often appear not to be connected when system elements interact with the controlling system (e.g. within budget system). It leads to estrangement of microeconomic agents from economy regulation at the microeconomic level. As it was shown in [105], for the taxation system it means tax evasion and collapse of the state budget system in general. Therefore, a conclusion was drawn that not market but ethic effectiveness is the condition for the state interference; the state redistributes finances if it provides run-up of taxpayers' usefulness as a result of recipients' usefulness run-up (a reverse downward link).
In their monograph "Hierarchical Analysis of Economy: Method and Models” (2008) [89], Yu. K. Persky and D. N. Shults defined a problem of uncontroversial description of micro- and macroeconomy and showed that such sort of description is only possible in case of linear homogenous economy. So the "statistical" method of aggregate production functions was suggested.

Taking the economy of the USA as an example, they demonstrated that branches can be described with the help of Cobb-Douglas production functions $Y=A L \alpha K \beta$, whose parameters $A$, are allocated according to the normal probability law. In this case aggregate production function of the USA differs from Cobb-Douglas function and is as follows

$$
F(K, L)=n M[A] L^{M[\alpha]+\frac{1}{2} \sigma^{2}[\alpha] \ln (L)} K^{M[\beta]+\frac{1}{2} \sigma^{2}[\beta] \ln K},(1)
$$

where $n$ is the number of branches in economy, $M[\cdot]$ is mathematic expectation of a corresponding parameter of production function, $\sigma 2[\cdot]$ is dispersion of production function parameters, $L$ is labor aggregate costs (e.g. in billion dollars), $K$ is the cost of basic funds (e.g. in billion dollars).

The authors showed that production functions are not invariant in relation to the economic hierarchy level. In terms of system analysis it means that economy as a system possesses the property of emergence. For economic theory this conclusion means that microeconomic level regularities cannot be transferred to the macroeconomic level. For the 
methodology of economics it would mean an incorrect application of the representative agent method.

Furthermore, the authors of the research stated that they could refuse the requirement for uncontroversial description of micro- and macroeconomy. In physics Bohr's principle of complementarity allows for thinking about the world at the quantum level as probable and non-equilibrium and at the macrolevel as being determined and ordered. Thus, a hypothesis was proposed that economy can also be simultaneously represented as equilibrium and optimal at its microlevel and as non-equilibrium and taking government regulation at the macro one.

At the same time, synthesized macroeconomic production functions allow for modeling and forecasting national economy more precisely. In the following papers [100; 101] the statistical method was generalized for non-homogeneous economic structure, for the Leontief production functions and constant elasticity of substitution (CES), for the cases of statistical distributions different from normal. For the Russian economy in particular it was found that the regions could be described with the Cobb-Douglas production functions and that elasticity of labor outcome had a lognormal distribution while that of investments had a normal distribution. Thus, the aggregate production function of the Russian Federation is as follows

$$
F(I, L)=n M[A]\left(\frac{I}{n}\right)^{M[\beta]+\frac{1}{2} \sigma^{2}[\beta] \ln \left(\frac{I}{n}\right)} \int_{0}^{\infty}\left(\frac{L}{n}\right)^{\alpha} \frac{1}{\alpha \sqrt{2 \pi} \sigma_{\alpha}^{2}} e^{-\frac{\left(\ln (\alpha)-\mu_{\alpha}\right)^{2}}{2 \sigma_{\alpha}^{2}}} d \alpha .
$$

And finally, in the study the attempt was made to extend hierarchical analysis to such economic levels as nano-, meta-, meso-, and megalevel (Table 2).

Levels of economy and their structure

\begin{tabular}{|c|c|c|c|c|}
\hline \multicolumn{2}{|c|}{$\begin{array}{c}\text { Economic } \\
\text { levels }\end{array}$} & Level elements & Linkages between elements & Level as a system \\
\hline \multirow{6}{*}{ 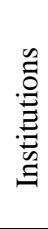 } & Nano- & Individuals & Linkages between individuals & Microeconomic objects \\
\hline & Micro- & Entities & Market links & General economic equilibrium \\
\hline & Meta- & Markets & Linkages between markets & - \\
\hline & Meso- & Regions, branches and FIG & Interregional and interbranch linkages & - \\
\hline & Macro- & Macro entities of economy & Macro markets & Economy as a whole \\
\hline & Mega- & Countries and transnational corporations & Linkages between countries, global markets & Global economy \\
\hline
\end{tabular}

More than that, a hypothesis was put forward that an economic system can be represented as fractal, i.e. a system in which each element reflects the whole system (Fig. 3). Figuratively speaking, economy is a sort of a nested doll, whose each lower level is a reflection of higher levels and inherits some their properties.
This representation appears to be rather interesting. If its correctness finds its confirmation, the application of microeconomic methods, including management and marketing, will be justified for the use in macroeconomics. And it will also be possible to use macroeconomic models in microeconomic analysis.

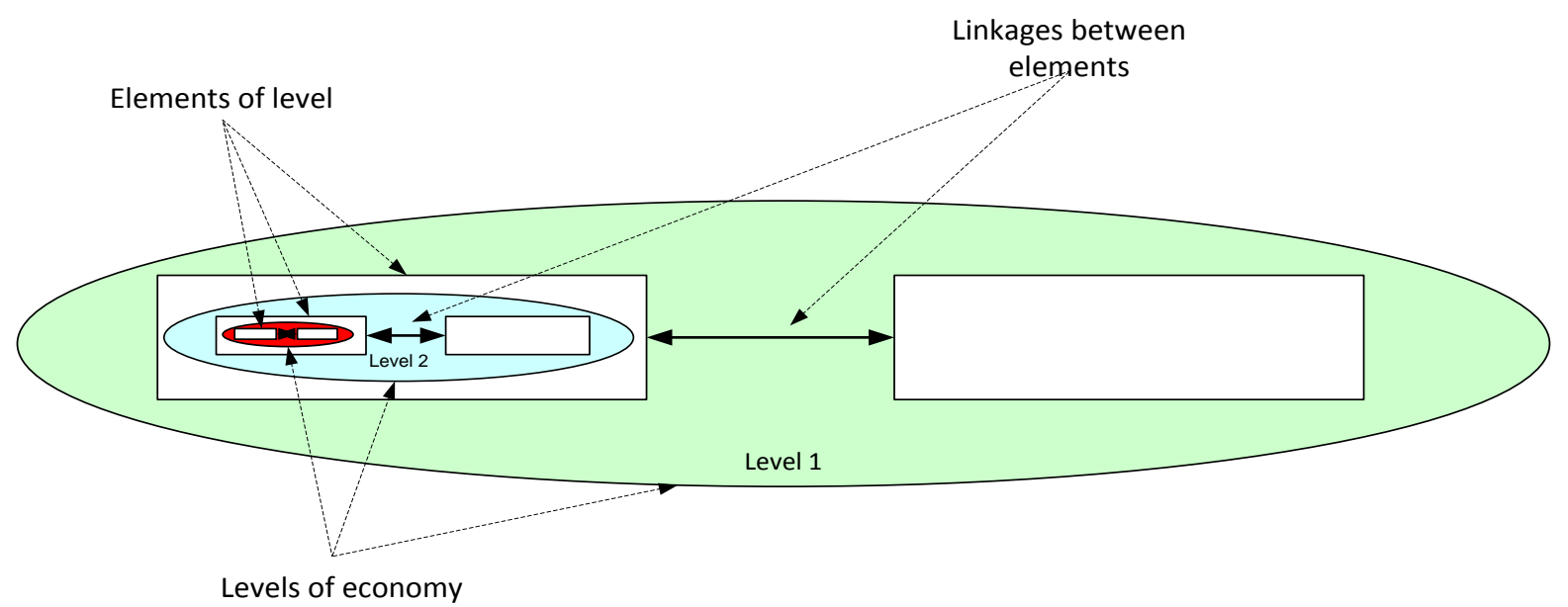

Fig. 3. Economy as a fractal hierarchical system

\section{Study and modeling of reproductive interaction between territorial socio-economic systems}

Theoretical methodological statements of hierarchical analysis served as a basis for the research into the individual and multifaceted nature of the development of reproduction processes in territorial socio-economic systems conducted by E. Zhulanov. The research helped to admit the necessity for formulation and solution of an urgent problem of economic mathematical modeling of hierarchically arranged reproductive interactions of the systems under discussion. Solu- tion to the problem became possible due to the development of the integral methodology of economic mathematical modeling, which lets scientists conduct profound and highly reliable measurements and forecast the results of economic processes functioning and control them in territorial economic space [108]. Nonlinear methods of description of the processes taking place at each level of territorial hierarchy formed the basis for the work. The research was aimed at analyzing the nature and methods of measurements of the results of territorial systems interlevel interaction. It allowed for focusing on determination and use of the 
synergy potential of territorial systems belonging to all hierarchical levels for the benefit of their strategic development.

The major hypothesis of the research was that hierarchically arranged interaction of territorial socioeconomic systems self-developing in national economic space can only be provided when modeling their cluster-network contours, which are socio-economic systems being subject to measurement, reproducing the most important conditions of their functioning and interacting with the environment. Modeling of the contours involved building up balance models having nonlinear cross-market economic relations; these are formed with the use of power production functions and the method of Lagrange multipliers, allowing for modeling consumer resources choice at minimal expenses.

The study of the problem of territorial socioeconomic systems interaction made it possible to determine development of the concept of territorial socioeconomic reproduction contours as theoretical basis for its solution. This concept presents an integral theoretical and methodological interpretation of economic measurements of reproduction processes of territorial systems' socio-economic activity. It can also serve as a basis for building up their interaction management system. The above ideas have found their expression in the following results.

First, methodological principles used when defining reproduction contours have been stated and justified:

- economic and administrative contours borders are defined basing on the subadditivity effect, which means that economic management should be carried out by two of more systems in case if onesystem management appears to be more expensive;

- a system (subsystem) defined within the contour has to contain elements which would form reproduction cycle and provide reproduction principle of the contour's building and development;

- the subject of the contour's management synchronizes functioning of all its elements and their interaction with the external environment, which is aimed at the contour's development;

- economic parameters of a reproduction contour are formed on the basis of market regulators, which imply rational behavior of economic entities trying to minimize their expenditures as well as free pricing in all kinds of activity except those likened to natural monopolies;

- economic growth factors are the basis for economic processes arrangement within the contour, they also provide reproduction processes when interacting with the external environment of the contour;

- the contour to be found has to be embedded into a higher order contour, which would serve as its external environment, and also has to connect the elements whose performance corresponds the whole system properties, which are emergence, multiplicity, adaptability, reliability, integrity, equifinality, purposefulness, structuredness, alternativeness of functioning and development, communicativeness, synergy, hierarchical nature;

- the transition from a lower level reproduction contour to a higher level one takes place as soon as differences in the conditions of economic activity appear because they produce new elements in subsystems; these elements are not common for the system in general but require being taken into account during the management process as they influence market prices of production resources or market conditions.

Second, the above principles assisted to define municipal, regional, and national reproduction contours and to justify theoretical value of the hierarchical structure of economic growth factors (Fig. 4) as a basis for the development of methodological approaches to economic measuring and modeling of territorial systems and the instrumentarium in order to balance socioeconomic disproportions of territorial systems and develop mechanisms to control their interaction [108, p. 107-122].

\section{Factors of economic development of the national reproduction contour:}

1) institutional factors; 2) mechanism of regulating socio-economic asymmetry of the regions

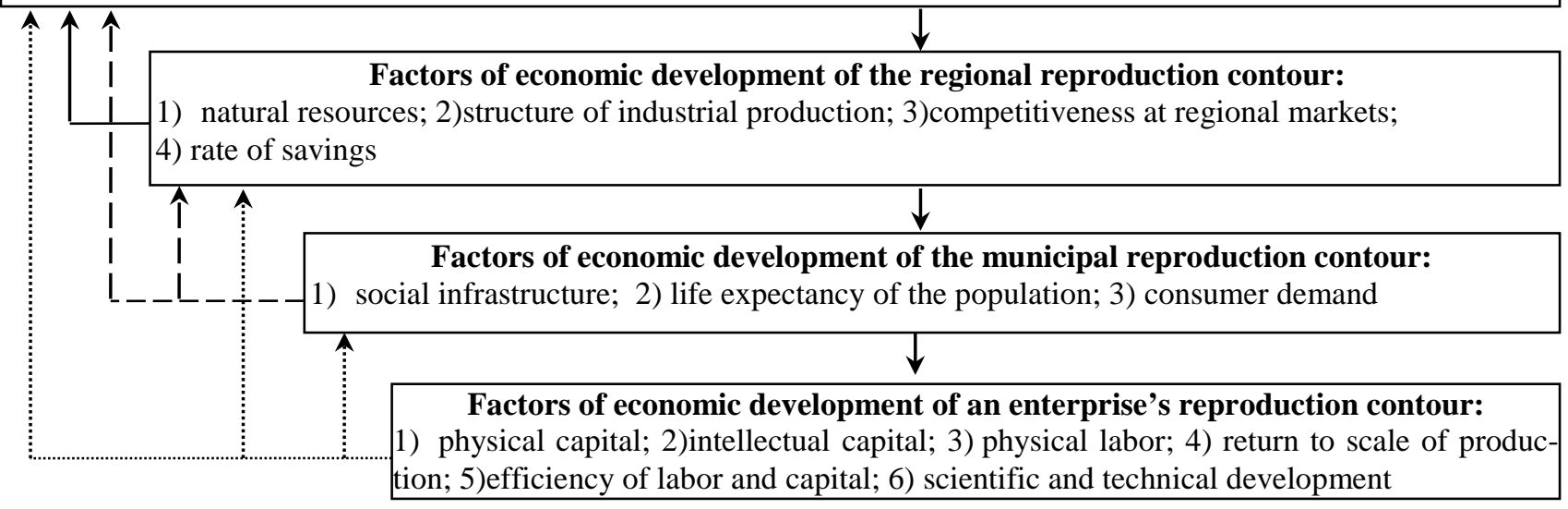

Fig. 4. Hierarchical multiplicative interdependence of factors of reproduction contours economic growth

Third, a new concept has been introduced - a "model of territorial socio-economic reproduction con- tour” - meaning a complex of measurable variable parameters and reflecting system connections of such 
processes as reproduction of commodities, capital and population employment in a competitive market economic space within the frames determined by the homogeneity of the conditions of functioning and individual features of the structure resulting from the contour's role and place in the economic and administrative hierarchy as well as by economic growth factors. Unlike the existing neoclassical and post-Keynesian models of economic development and their modern analogues, the concept introduced considered interconnected and interacting socio-economic systems and their elements as an object of modeling, which made it possible to extend the analysis of the results of national economy's functioning. The reproduction contour appeared to be a complex of methods and models of economic measurements of parameters of activity and territorial socio-economic interaction management [108, p. 98-100].

Fourth, a model of municipal reproduction contour's functioning has been developed, representing reproduction of commodities, services and employment for providing population with standards of living. This contour is depicted in a graphic form in Fig. 5. For the first time the model is based on non-linear economic relations between municipal markets formed by the combination of extra-market regulations and principles of market conduct for economic entities reducing their expenditures. The model was developed with the use of power production functions with a built- in mechanism of market conduct and is based on the Lagrange method and the instrumentarium of distribution of municipal tariffs for the goods and services of social infrastructure. The model can substitute the interindustry balance method and unlike that allows for forecasting a balanced economic development of reproduction processes in the municipal contour under the influence of market demand change and tariff regulation by local authorities. The model can also be used for economic evaluation of the above regulation [108, p. 157-168, 199-218, 114].

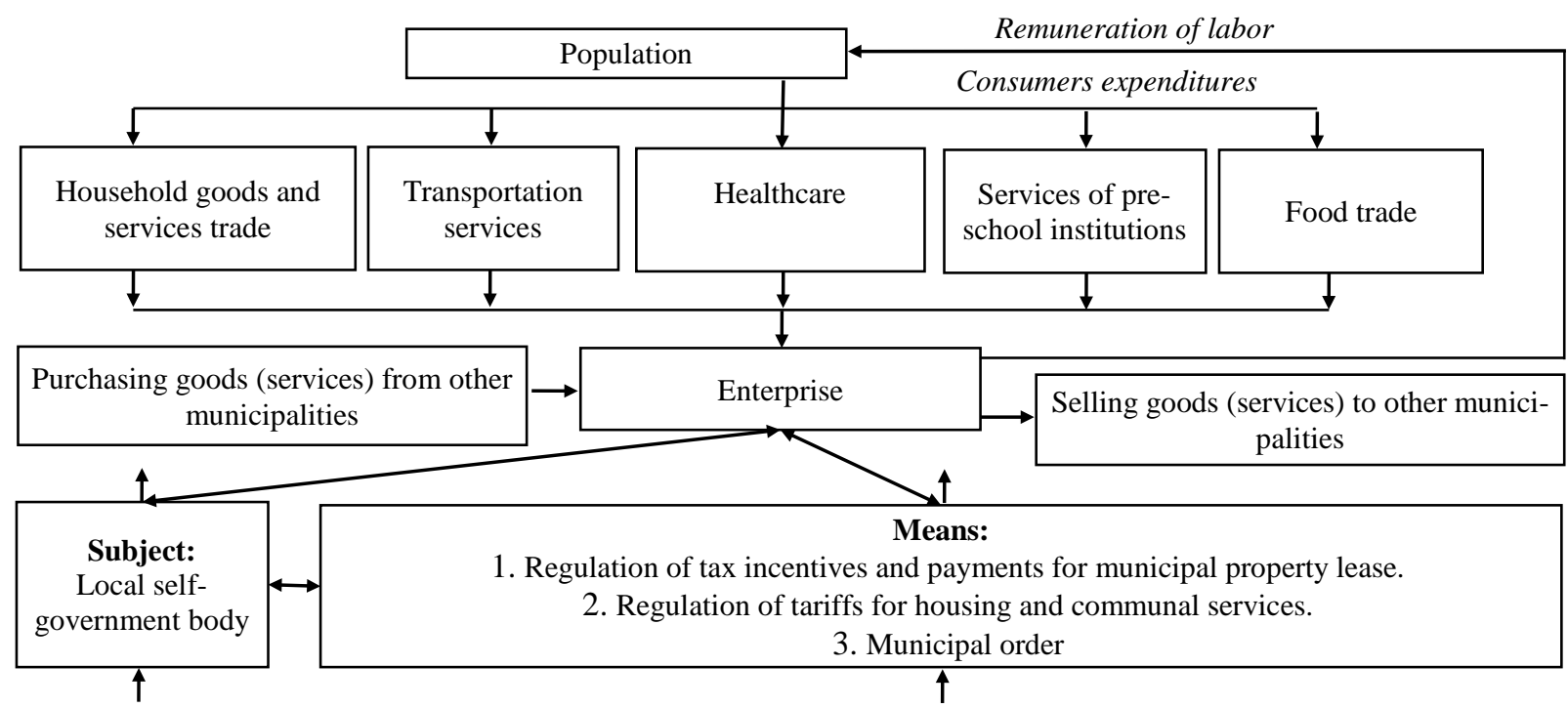

Fig. 5. Reproduction contour of a municipality

Fifth, the research provides economicmathematical description of the essence of the regional contour producing goods, services, capital and employment in the regional markets system under the corresponding socio-economic and natural and climatic conditions. This description develops methods of endogenous modeling of socio-economic systems under the conditions of territorial differentiation of their elements. The contour is depicted in the graphic form in Fig. 6. For the first time a model has been proposed allowing for formation of non-linear economic relations between regional markets based on power production functions with a built-in mechanism of enterprises expenditure reduction and also for changes in power production elasticity under the influence of innovations and rise of labor professional level [108, p. 169-188, 218-248]. A theoretical game approach to modeling enterprises strategic interaction on regional markets has also been developed, this being embedded into the regional contour model [111]. The functional purpose of the model results from the necessity for forecasting a region's economic development taking into account changes in consumer demand and competitiveness regulation as well as from the necessity for economic evaluation of these regulations.

One more method has been developed for leveling socio-economic asymmetry in development of reproduction contours on the basis of justification of hierarchical interactions of the factors changing their boundaries and interregional differentiation of tax rates, influencing changes in commodity, finance and migration flows between the given contours. The method is based on the unique author's mechanism allowing for defining and differentiation of tax groups capable of bringing some economic benefit to economic entities when these flows change. The mechanism differentiates tax rates according to the ratio of the tax basis of the leading regional contour and a less developed one and increases index method application for tax regulation. 

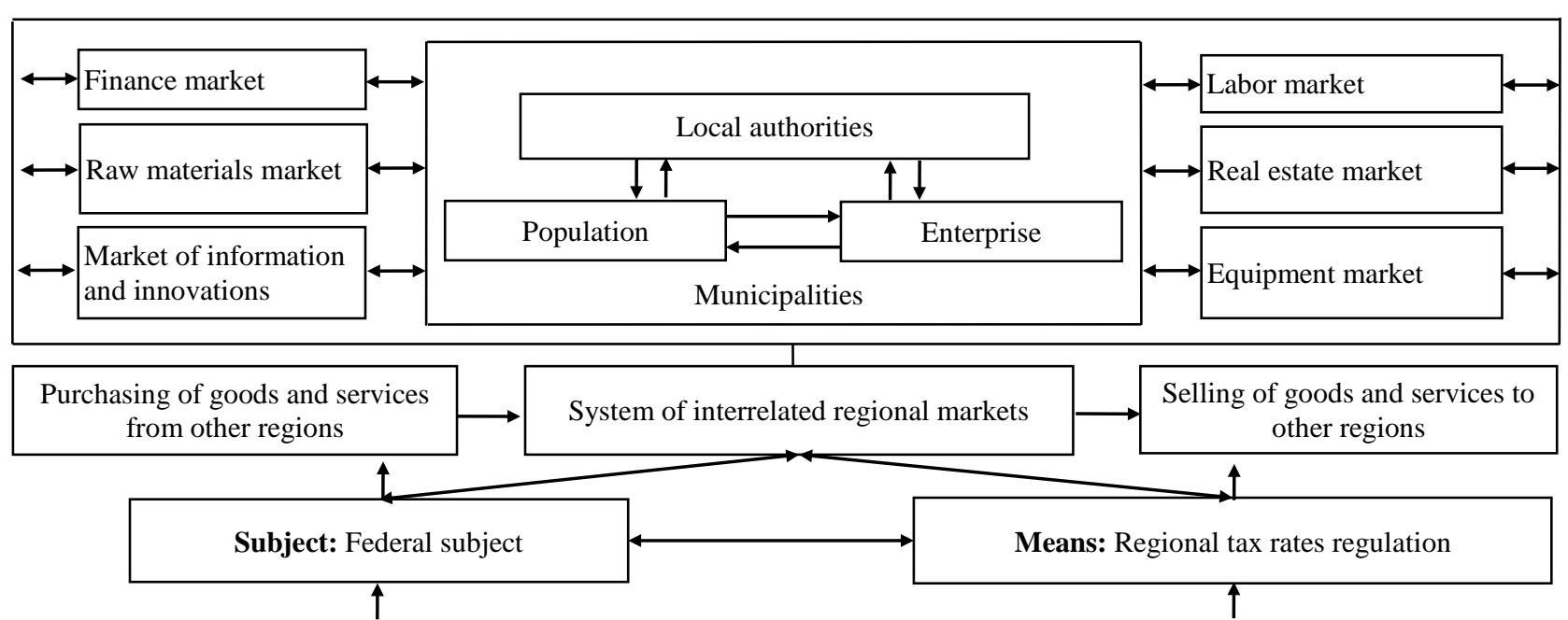

Fig. 6. Reproduction contour of a region (subject of the Russian Federation)

Sixth, to evaluate changes in the flows, linear connection between economic benefit of economic entities and tax rates has been found. This gave an opportunity to suggest a new application of the linear programming apparatus, which would greatly increase economic benefit of economic subjects from selling goods, investments into other regions and workforce migration [111, p. 93-137; 108, p. 248-264; 109].

Seventh, a hierarchically integrated model of the national reproduction contour has been built, which develops interbrunch balance method of national economy's modeling due to the merge of cross-market goods (services) flows, produced by regional contours, whose management results depend on hierarchical management efficiency in lower level systems and external economic activity regulation. This contour is represented in Fig. 7. The model is an innovative tool for forecasting changes in value added from various combinations of hierarchical management of reproduction contours, taking into account free offer and demand at markets and conduct of their participants. In the course of the study, a method of forecasting of production scale based on quantitative characteristics of price and non-price factors of its elasticity has also been justified and integrated into the model. This considerably specifies the mentioned balanced method, which implies changes in production only based on demand. The model also shows relations not between industries but between markets for goods and services, which allows one to form economic relations according to the market conditions. The model suggested provides a system equilibrium of the national reproduction contour [108, p. 188-198, 265-277; 110].

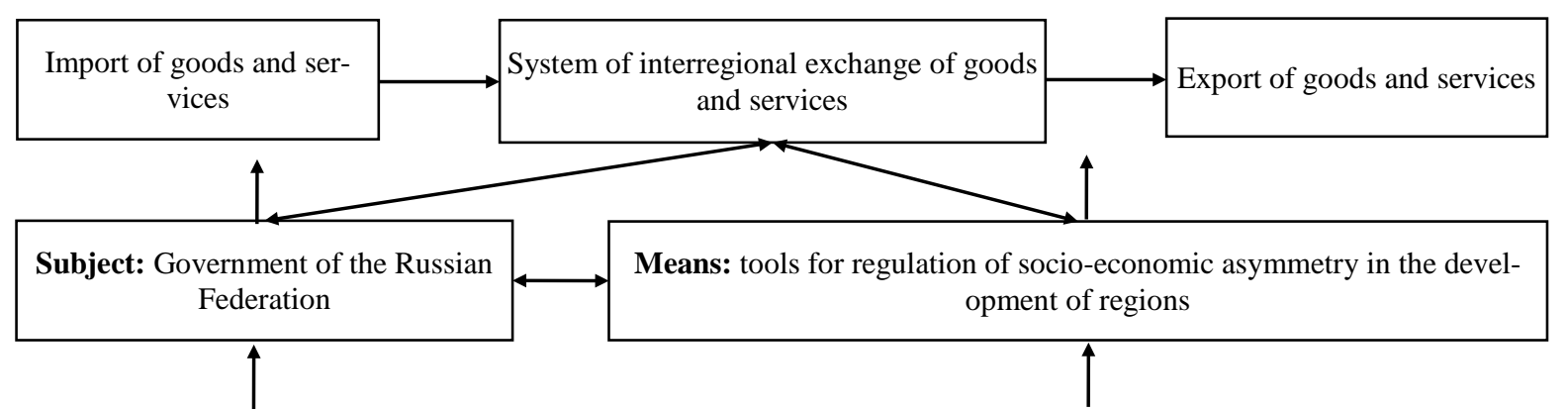

Fig. 7. Reproduction contour of the national economy

Eighth, hierarchical linkages between factors of reproduction contours have been found and the authors suggested theoretical methodological justification of a complex, system-based measurement of reproduction contours hierarchical management, considering the fact that they have a multiplicative influence on each other and on the factors of economic development of contours. It helped to form a mechanism of harmonization for managing functioning of socio-economic systems of reproduction contour $\mathrm{s}$ of all levels. This mechanism appears to be an advanced model adding synchronized national economy management into the field of dynamical programming models application. The model is developed to forecast added value changes due to selection of the most favorable combination of administrative decisions both along the contours hierarchy and between contours of the same level, taking into account free offer and demand at the markets and conduct of their participants [108, p. 122-155].

The research conducted allowed for suggesting a new methodological approach to the management process formation, which reflects the state and trends of territorial socio-economic systems development. Administrative decisions being taken are considered now as the mean to overcome contradictions in the development of systems of different levels; these contradictions can occur due to regional differentiation of business activity conditions. The above mentioned modeling of territorial socio-economic systems relations served as a tool basis for decision-making. Be- 
sides, the research under discussion resulted in increased understanding of the cluster-network nature of territorial socio-economic systems relations. It agrees with the match and unity of the levels of the national socio-economic system hierarchical structure and cluster-network systems having individual development purposes and the mechanism able to manage the interaction between their constituents. The management conception can provide multiplicative and synergetic results from hierarchical management of interaction between territorial socio-economic systems which create hierarchical cluster-network formations [112].

3. Structuring and designing of the system of institutions: prospects of the hierarchical approach (through the example of the system of gender power institutions)

At present, economics as a science differentiates three basic levels in any institutional system. These are non-constitutional (informal), constitutional and economic (formal) rules, which form an integral unit, interacting with each other, complementing and substituting each other. According to D. Nort, it is generally accepted to define two types of possible relations between formal and informal rules [66, p. 67]. The first one is when formal rules can supplement informal ones and thus make them more effective. In this case, formal and informal rules match each other or can be complements towards each other. If formal and informal rules are coherent, the necessity for strict public control gets lower as informal enforcement control can be sufficient. Thus, the function of law is just to remind of the social value of offences, i.e. to prescribe appropriate behavior and inform that those who do not follow the established rules will be publically condemned. If formal and informal rules are complements towards each other, these can enforce economic agents to various behaviors, being nevertheless compatible and aimed at one and the same social purpose; each of the rules taken separately is insufficient.

According to the second type, formal rules can be introduced in order to modify, revise or alter informal restrictions. In this case, formal and informal rules might not match each other and they exist as independent public control systems or can even be contradictory. If different groups of rules are in conflict, it has a harmful effect on the economic development because public control has to become stricter and so does the enforcement to following formal rules.
Therefore, it should be noted that the given institutions taken together form a hierarchical system of institutions. Being separate parts of any system, they are closely connected with each other and develop together with the system itself. However, modern economics does not pay enough attention to the analysis of the influence of different hierarchy levels on each other. As it has already been found [6], the type of connection between the elements of the system, coherence of their purposes and functions, and the extension of the system, which in fact define the wholeness of any institutional system as they indicate its complete structure and closeness of internal relations between its elements, are among basic quality characteristics, possessed by any functioning institutional system. Thus, one cannot ignore data of determinants; otherwise, it would be impossible to determine precisely the original quality of the system of institutions and detect the causes of its malfunction.

Hence, to define the original quality of the system more accurately and accordingly determine possible strategic imperatives of the development of the institutional systems under investigation, it is necessary to perform structuring of any system, that is to study all linkages between the system's elements. It means that there is a transition from treating the system of institutes as a part of external space to its understanding as a combination of internal elements and their connections. For this analytical operation, the use of hierarchical analysis tools is the most productive.

According to E.V. Bazuyeva, the method of hierarchical analysis was used to study the boundaries and the type of interaction between the gender power institutions functioning in the current Russian economy.

Gender power institution is a special type of socio-economic institution being formed under the influence of some objective conditions of material production (social division of labor), which can be represented in the form of a system of rather stable relations of power formalized through the system of legislative acts, contracts and informal rules that regulate the forms of interaction between the subject and the object of power and determine purposes and variants of their own lifestyle and conduct model.

Fig. 8 depicts the process of interaction between these institutions. 


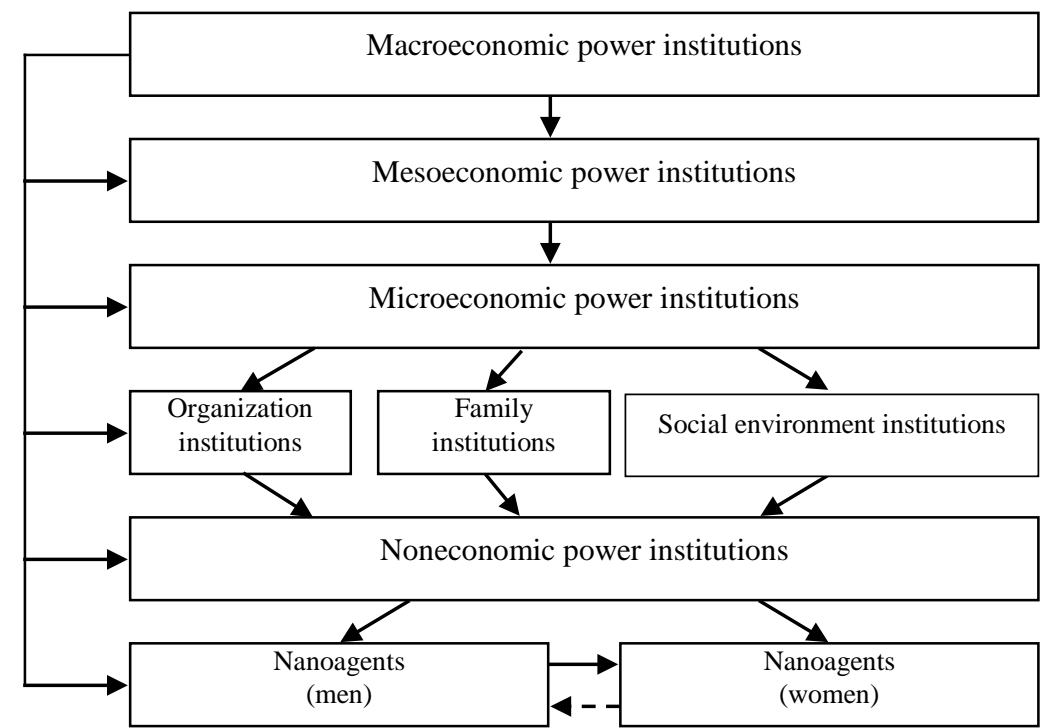

Fig. 8. Hierarchical system of gender power institutions in the modern economy of Russia

Nota bene: in Figs. 8, 9 and 10 direct and reverse linkages of power influence at different levels of the system of gender power institutions are marked by full and dashed lines respectively.

Spatial -functional description of gender power is given in Table 3. For further details of the analysis of interaction and linkages between gender power insti- tutions as factors determining the quality of the given hierarchical system functioning at different hierarchy levels, refer to $[7 ; 8 ; 14 ; 17 ; 18]$.

Table 3

Hierarchical system of gender power institutions in modern Russia

\begin{tabular}{|c|c|c|c|c|c|c|}
\hline \multirow{2}{*}{$\begin{array}{l}\text { Institutions } \\
\text { (subjects) }\end{array}$} & \multirow{2}{*}{$\begin{array}{c}\text { The object of } \\
\text { power }\end{array}$} & \multirow{2}{*}{$\begin{array}{l}\text { Purposes of } \\
\text { the power }\end{array}$} & \multirow{2}{*}{$\begin{array}{c}\text { Functions of the } \\
\text { power }\end{array}$} & \multicolumn{2}{|c|}{ Gender power disposition } & \multirow{2}{*}{$\begin{array}{l}\text { Types of sanctions } \\
\text { for breaches of the } \\
\text { power disposition }\end{array}$} \\
\hline & & & & Content & $\begin{array}{c}\text { Institutional } \\
\text { role }\end{array}$ & \\
\hline $\begin{array}{l}\text { The power of } \\
\text { the state }\end{array}$ & $\begin{array}{l}\text { All economic } \\
\text { agents of the } \\
\text { national econ- } \\
\text { omy }\end{array}$ & $\begin{array}{l}\text { Establishment } \\
\text { of fundamen- } \\
\text { tal rules of } \\
\text { economic } \\
\text { behavior. } \\
\text { Provision of } \\
\text { economic and } \\
\text { civil rights } \\
\text { observance }\end{array}$ & $\begin{array}{l}\text { Appears to be the } \\
\text { foundation for } \\
\text { the power of } \\
\text { private economic } \\
\text { agents, based on } \\
\text { property posses- } \\
\text { sion or power } \\
\text { rights provided } \\
\text { by the state }\end{array}$ & $\begin{array}{l}\text { Restriction of access to } \\
\text { resources and goods. } \\
\text { Fixation of formal gender } \\
\text { equality. } \\
\text { Priority state funding of so } \\
\text { called "male" economic } \\
\text { branches. } \\
\text { Women get the status of a } \\
\text { worker having family } \\
\text { obligations and a major } \\
\text { social services user }\end{array}$ & $\begin{array}{l}\text { A man is a } \\
\text { professional } \\
\text { worker, a } \\
\text { woman is a } \\
\text { working } \\
\text { mother }\end{array}$ & $\begin{array}{l}\text { State enforcement } \\
\text { system }\end{array}$ \\
\hline $\begin{array}{l}\text { The power of } \\
\text { the organiza- } \\
\text { tion }\end{array}$ & $\begin{array}{l}\text { Staff of the } \\
\text { organization. } \\
\text { Other organi- } \\
\text { zations inter- } \\
\text { acting with it. }\end{array}$ & $\begin{array}{l}\text { Direct influ- } \\
\text { ence on the } \\
\text { behavior of } \\
\text { other econom- } \\
\text { ic and state } \\
\text { agents }\end{array}$ & $\begin{array}{l}\text { Profit maximiza- } \\
\text { tion due to the } \\
\text { use of cheaper } \\
\text { and lower-skilled } \\
\text { female labor }\end{array}$ & $\begin{array}{l}\text { Loss of a part of income } \\
\text { due to its confiscation by a } \\
\text { subject of power (gender } \\
\text { gap in payment for labor). } \\
\text { Dependence of vacancies } \\
\text { on the presence of family } \\
\text { obligations. Sexual abuse } \\
\text { can be practiced by male } \\
\text { managers towards women } \\
\text { to be promoted }\end{array}$ & $\begin{array}{l}\text { A man is a } \\
\text { worker hav- } \\
\text { ing no fami- } \\
\text { ly obliga- } \\
\text { tions; a } \\
\text { woman is a } \\
\text { worker with } \\
\text { family obli- } \\
\text { gations }\end{array}$ & $\begin{array}{l}\text { Enforcement system } \\
\text { adopted in the or- } \\
\text { ganization and per- } \\
\text { formed by the or- } \\
\text { ganization itself }\end{array}$ \\
\hline $\begin{array}{l}\text { The power of } \\
\text { the social } \\
\text { environment }\end{array}$ & $\begin{array}{l}\text { Participants of } \\
\text { the group }\end{array}$ & $\begin{array}{l}\text { Control over } \\
\text { the behavior } \\
\text { of the group's } \\
\text { participants }\end{array}$ & $\begin{array}{l}\text { Formation of a } \\
\text { gender stereo- } \\
\text { typed model of } \\
\text { life and behavior }\end{array}$ & $\begin{array}{l}\text { Implementation of stand- } \\
\text { ard models of life and } \\
\text { behavior: women are } \\
\text { working mothers or } \\
\text { housewives, men are } \\
\text { breadwinners }\end{array}$ & $\begin{array}{l}\text { A man is a } \\
\text { breadwinner } \\
\text { and the head } \\
\text { of the fami- } \\
\text { ly; a woman } \\
\text { is a house- } \\
\text { wife }\end{array}$ & $\begin{array}{l}\text { Sanctions per- } \\
\text { formed by the social } \\
\text { group (public con- } \\
\text { demnation) }\end{array}$ \\
\hline $\begin{array}{l}\text { The power of } \\
\text { the family } \\
\text { represented } \\
\text { by its head }\end{array}$ & $\begin{array}{l}\text { Women and } \\
\text { men }\end{array}$ & $\begin{array}{l}\text { The use of the } \\
\text { power object } \\
\text { resources to } \\
\text { secure power } \\
\text { rent }\end{array}$ & $\begin{array}{l}\text { Maximization of } \\
\text { benefit for the } \\
\text { subject of power, } \\
\text { which is mani- } \\
\text { fested in obtain- } \\
\text { ing power rent } \\
\text { and opportunities } \\
\text { to move beyond } \\
\text { the limits of its } \\
\text { resources }\end{array}$ & $\begin{array}{l}\text { Household duties are to be } \\
\text { separated according to the } \\
\text { gender. The breadwinner } \\
\text { defines the type of the } \\
\text { family, professional } \\
\text { sphere, leisure activities }\end{array}$ & $\begin{array}{l}\text { A man is a } \\
\text { breadwinner } \\
\text { and the head } \\
\text { of the fami- } \\
\text { ly; a woman } \\
\text { is a house- } \\
\text { wife }\end{array}$ & $\begin{array}{l}\text { Sanctions are cho- } \\
\text { sen depending on } \\
\text { the type of gender } \\
\text { power and are per- } \\
\text { formed individually }\end{array}$ \\
\hline
\end{tabular}




\begin{tabular}{|c|c|c|c|c|c|c|}
\hline \multirow{3}{*}{$\begin{array}{c}\text { Institutions } \\
\text { (subjects) }\end{array}$} & \multirow{3}{*}{$\begin{array}{c}\text { The object of } \\
\text { power }\end{array}$} & \multirow{3}{*}{$\begin{array}{l}\text { Purposes of } \\
\text { the power }\end{array}$} & \multirow{3}{*}{$\begin{array}{c}\text { Functions of the } \\
\text { power }\end{array}$} & \multirow{3}{*}{\multicolumn{3}{|c|}{$\begin{array}{l}\text { The end of table } 3 \\
\text { Types of sanctions } \\
\text { for breaches of the } \\
\text { power disposition }\end{array}$}} \\
\hline & & & & & & \\
\hline & & & & & & \\
\hline $\begin{array}{l}\text { Internal pow- } \\
\text { er }\end{array}$ & $\begin{array}{l}\text { Women and } \\
\text { men }\end{array}$ & $\begin{array}{l}\text { Internal con- } \\
\text { trol over its } \\
\text { own behavior }\end{array}$ & $\begin{array}{l}\text { Modification of } \\
\text { the structure of } \\
\text { purposes and } \\
\text { motivation tak- } \\
\text { ing into account } \\
\text { requirements of } \\
\text { the subject of } \\
\text { power }\end{array}$ & $\begin{array}{l}\text { Position stereotypes are in } \\
\text { progress. Household du- } \\
\text { ties are to be strictly sepa- } \\
\text { rated according to the } \\
\text { gender. Male and female } \\
\text { behavior has to match the } \\
\text { gender status }\end{array}$ & $\begin{array}{l}\text { A man is a } \\
\text { breadwinner } \\
\text { and the head } \\
\text { of the fami- } \\
\text { ly; a woman } \\
\text { is a house- } \\
\text { wife }\end{array}$ & $\begin{array}{l}\text { Internal sanctions } \\
\text { dependent on moral } \\
\text { norms (a feeling of } \\
\text { remorse, guilt) }\end{array}$ \\
\hline
\end{tabular}

The given system of institutions can be ineffective due to blurring of limits of power in the macrolevel institutions (national and regional government institutions); strengthening of gender power in microlevel institutions (internal power institutions, family power institutions, social environment power institutions, organization power institutions); uniformity of power disposition for subjects located at the same level of the hierarchy; incoherence of purposes and functions of the institutions located at the same level of the hierarchy; population's low awareness of forms and factors of gender power appearance; lack of feedbacks and horizontal linkages between the levels of the system.

The system of institutions described above has proved to be dysfunctional in terms of its basic institutions (rules), which means its low quality and inefficiency as following the standards of conduct (institutional roles) set by this system is too costly for economic agents at all its levels $[7 ; 8 ; 12 ; 18]$. Thus, it is necessary to modernize the existing gender power institutions system in order to increase its egalitarian features. Institutional designing has been chosen as a strategy for institutional alteration; it is a controlled gradual replacement of some institutions by other ones, which is currently considered to be the most successful path of institutional changes [11].

The researchers used synthesis of apparatus of institutional economic theory and that of hierarchical analysis when defining probable strategic imperatives for developing the system of gender power institutions of the egalitarian type in modern Russia. This system of institutions implies gender power is limited by the sphere of freedom of another economic agent, so its concentration is quite low. It implied the essential use of analytical structuring operation at each stage of the institutional project development:

1. Analysis of evolution and experience of transfer of similar institutional subsystems in developed countries;

2. Comparing transfer strategies used by catching-up economies to the subsystems under discussion;

3. Study of Russian experience of functioning and borrowing of similar systems and search for the reasons for their failure;

4. Selection of elements possible to be transferred, their modification and matching them with the Russian conditions;

5. Decision on the sequence of intermediate institutions and the method for managing their transformation;

6. Search for the most effective transfer technique, including establishment of necessary auxiliary institutions, development of necessary alterations to legislation, and analysis of political processes connected with the approval of the reform plan [95, p. 207208].

Interinstitutional peculiarities of relations of the most effective gender power institutional systems acting in developed countries (Australia and Sweden) are considered in detail in $[7 ; 10]$. It is done on the basis of certain determinants of institutional systems' quality and their comparative analysis. The identified peculiarities of creating such systems and mechanisms of connecting gender power institutions with other institutional systems running in these countries were used when choosing the sequence of introducing intermediate institutions and the way of correcting the functioning formal institutions, which are in fact quasi institutions and do not perform their functions in the system of gender power institutions in Russia.

Besides, the experience of establishing the given institutional system in Poland has been analyzed. According to V. Poltrovitch, this experience will provide the opportunity "to adapt transfer strategies used by catching-up economies to the given subsystems" [95, p. 207]. Fig. 9 shows the results of the study of probable relations between gender power institutions in Poland.

The influence of the EU (external environment) appears to be the most important factor. This is of dual nature: on the one hand, it is a targeted action which implies the execution of international commitments (with the financial support from the EU) connected with gender equality; on the other hand, it is undeliberate influence (so called synergy effect) caused by creation of integrated European area. 


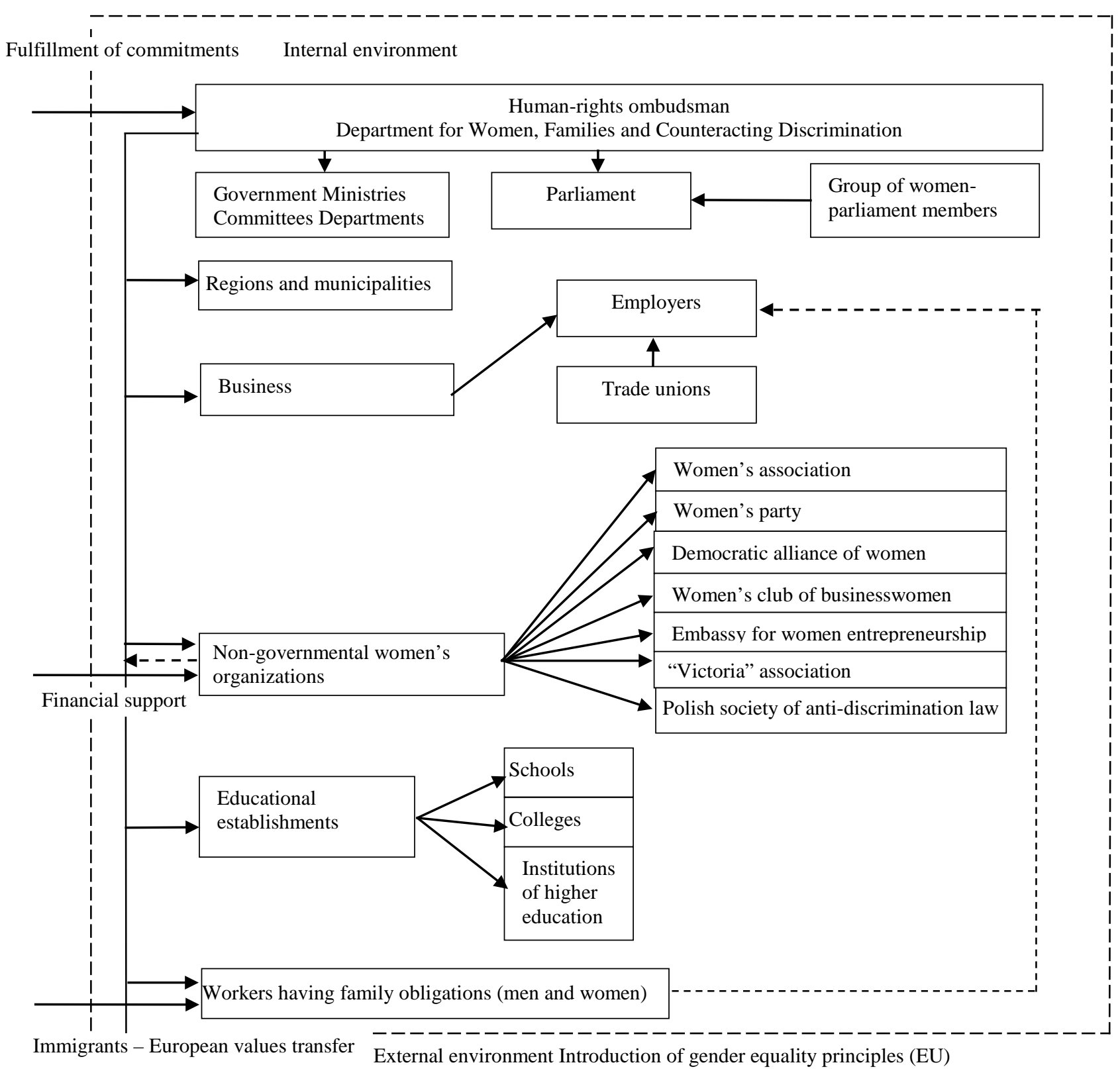

Fig. 9. Hierarchical system of institutions lowering the gender power level in Poland

It has been found that the above shown effects demonstrate the necessity for permanent enhancement of the gender power institutional system in Poland (its internal environment). It can be implemented in the following directions: 1) strengthening of the coordinating function of institutes of gender equality; 2) building up a vertical in the institutional system aimed at gender power evening-out at the regional and local levels of power; 3) integration of the gender approach into the activity of other ministries and departments; 4) development of the enforcement system to provide following the norms of egalitarian conduct at labor market. Among the major drawbacks of the given institutional system functioning, there are incoherence of purposes between high and low hierarchy levels, only direct linkages between institutions, "institutional vacuum" when creating mechanisms of introducing borrowed European institutions, inadequacy of sanctions and purposes, sanctioned conduct of agents at their work positions in the first place [14]. As the analysis has shown, the malfunctions revealed are to be taken into account when modernizing the gender power institution system in Russia. It would help not only to significantly cut the expenses but also to raise the level of adaptability of the institutes transferred.

Economic agents detecting and determining their demand when introducing the system of egalitarian gender power institutions in Russia are presented in [16]. It should be emphasized that the use of hierarchy analysis principles allowed us to find various types of equilibrium in modern families (egalitarian, traditional, transitive).

In families having egalitarian inner structure, household chores distribution is fair, reasonable; spouses can substitute each other when performing domestic tasks. The egalitarian structure does not leave space for responsibility differentiation according to the gender; decisions in such families are democratically made by all family members. Such type of gender interaction is only possible under the conditions close to those of competitive order, when concentration of gender power is quite low as it is limited by the sphere of 
another economic agent's freedom.

In traditional families, a man performs a role of a gender power subject while a woman is its object. Gender power disposition implies the following distribution of roles: a man is a breadwinner, an earner of market capital while a woman tries to accumulate so called "family" capital. It is assumed that a woman can be involved into public sector of economy but nevertheless housekeeping should be a priority for her.

The transitive type is an intermediate variant of gender relationships between spouses, when inner power institute influence decreases due to declining influence of stereotypes of position and changes in the economic agents' gender status. This type of gender power can be characterized by 1) decline of concentration of men's gender power in family economy in view of their greater involvement into housekeeping; 2) in- crease of the women's role in taking important decision (matriarchal model of family).

Thus, if the conditions of power disposition are coherent, even traditional type of gender power can be considered effective. These conditions are defined by the government institution, represented by its head and by the institute of internal power. However, in this case family is considered to be a closed system without any external influences. If family is treated as an open system with external influence factors (Fig. 10), then, according to the second principle of synergy, the gender power institutional system can become a highly effective synergetic system due to the intensive (streaming) exchange between the substance, energy and information and the environment under nonequilibrium conditions [36, p. 387].

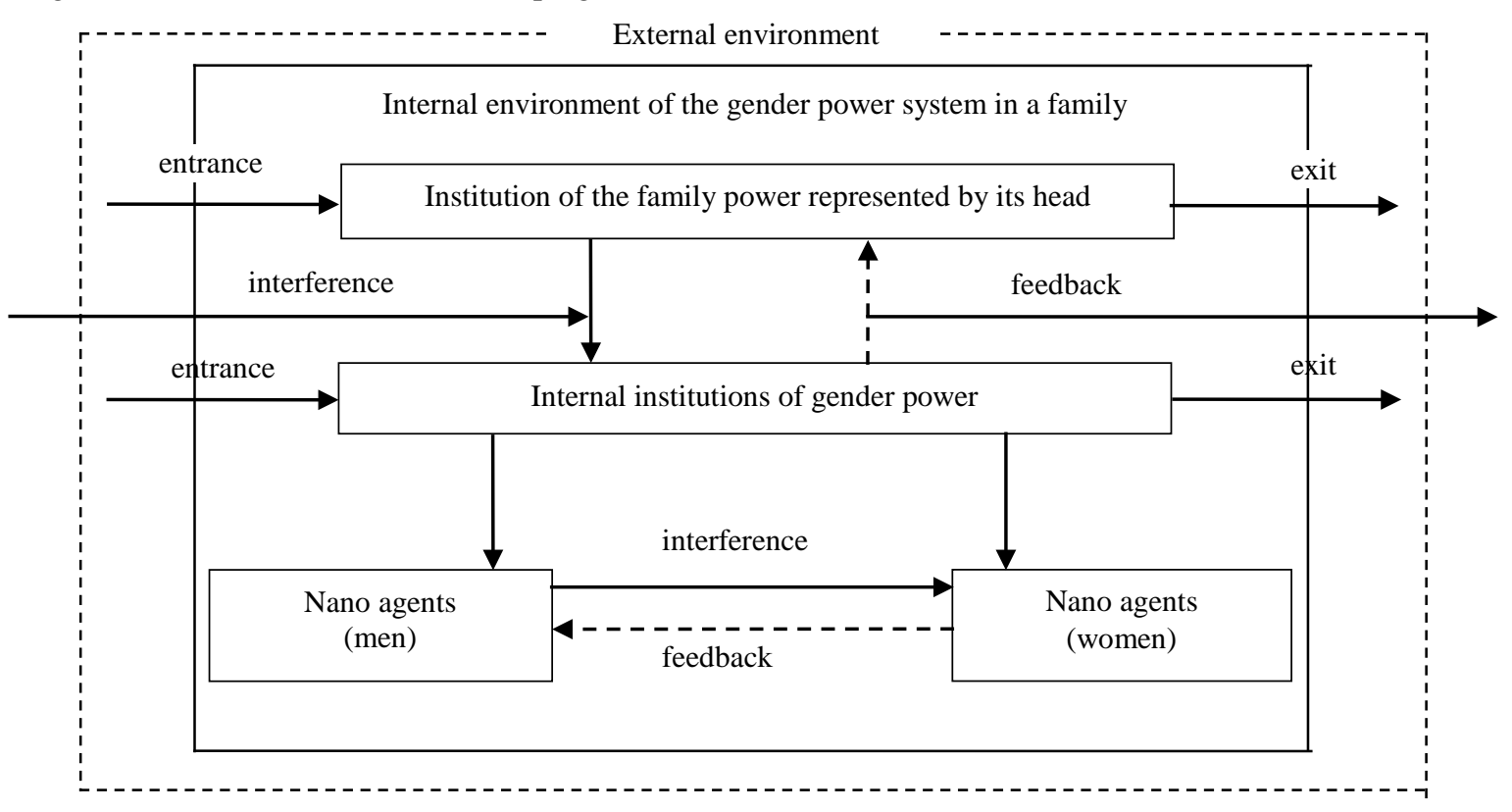

Fig. 10. Gender power institutions in family as a multilevel synergetic system

It looks like the trend towards disagreement in relations between spouses inside a family occurs due to incoherence of the purposes of gender power institutions functioning in the family and those situated at the upper levels of the hierarchy; these are social environment power, organization power, power of the state and region. Achieving equilibrium under these conditions is much harder since norms of conduct are destabilized, consequently, they possess low stability level; there is no order in their execution; there is a rise in transaction expenses connected with their application and relations with other norms of conduct. Consequently, agents appear that want to change gender behavior stereotypes. Thus, all the basic mechanisms necessary for institutionalization of behavioral norms, which are stability, coordination, integration, educating and inertia, do not work. These mechanisms were defined by V. M. Polterovitch [7; 12]. Besides, as it was revealed in researches $[7 ; 12]$, in terms of the socio-economic system's influence on the gender institutional system in general, the best way at the current stage of social development is reducing gender power concentration in the family economy, which would match the egalitari- an type of relations between spouses. Introduction of such kind of equilibrium is only possible under adequate institutional conditions, which confirms the fact that the system of egalitarian gender power institutions in Russian economy requires modernization.

Taking into consideration the peculiarities of the hierarchal analysis methods, three steps were suggested to modernize the system of egalitarian gender institutions in Russia [15].

The first stage includes building up direct linkages between egalitarian gender institutions which imply strict hierarchy of the levels in the institutional system, i.e. each of them has to determine egalitarian gender power disposition minimizing reproduction of traditional institutional roles of economic agents (men and women).

The second stage is aimed at development of the interinstitutional feedback system, which would allow for fast and on-time correction of the conditions under which institutions are able to perform their functions. Besides, the advanced feedback system would contribute into the reduction of the given hierarchical system operating potential by redistribution of expens- 
es and government rent between gender power agents located at different levels of the hierarchy.

The purpose of the third stage is the extension of horizontal interactions between the institutions, which would allow one to shorten hierarchical chains and the lag of institutional changes in the system and doing so to coordinate alterations between low and higher levels of the hierarchy and consequently would increase its functioning effectiveness in general.

To make norms of egalitarian conduct for economic agents stable, there are special stabilizing mechanisms at each of the enlisted stages. This provides coherence of their purposes so the given institutional system possesses synergetic effect of functioning.

Therefore, the use of hierarchical analysis principles when investigating institutional systems allows for giving a more detailed representation of the current institutional systems in national economies and for defining on this basis probable institutional paths of their effective modification.

\section{The hierarchical system of intellectual entrepreneurship institutions}

Under the supervision of Yu. Presky, T. Kovalyova studied the factors, regularity and models of intellectual entrepreneurship institutions formation; in this research further development of theoretical and methodological application of the institutional hierarchical approach to analysis of socio-economic systems was presented.

The term "intellectual entrepreneurship" is considered to be relatively young. It is believed that it was introduced into science by American researches Richard A. Cherwitz and Charlotte A. Sullivan [19]. The review of essential characteristics of intellectual entrepreneurship is given in papers [35, p. 286-308; 38; 52; 84].

According to the authors, intellectual entrepreneurship is a supra-cooperative complex of polyfunctional institutions regulating interaction between the subjects in the system of intellectual economic resources reproduction [26, p. 192].

Specific features of intellectual entrepreneurship according to the authors are:

- initial value orientation to the realization of intellectual potential of an individual, group of individuals, organization; microeconomic basis of entrepreneurship, i.e. economic income maximization is of secondary importance;

- creation, strengthening and development of special culture types (the culture of research, education, search, innovations, etc.);

- implementation of projects aimed at new knowledge generation and information distribution, creation and commercialization of innovations, new sectors (branches, clusters) of economy development;

- obtaining of market signals about peculiarities and efficiency of functioning of knowledge and information economic sectors [26, p. 192-193].

Modeling of intellectual entrepreneurship institutional structure is based on ideas and principles of the system analysis of an enterprise's internal environment developed by G.B. Kleyner [34, p. 128-140].

In particular, it was suggested to consider intellectual entrepreneurship institutional content as a complex structure of hierarchically arranged order of its constituents. The order of elements is defined by the following property: institutional space is built up from the higher to the lower element with account of the purpose of the institutes as well as the speed of institutional changes. Consequently, the institutional structure of intellectual entrepreneurship follows the logics of interlevel relations and interinfluence of its constituents.

Within the frames of the approach under discussion, modeling of internal content of intellectual entrepreneurship in the form of a multilevel pyramid has been done. Here each level represents one of its qualitatively different components in terms of fundamental and functional content of the institutional processes (Fig. 11).

According to the multilevel model, the base of the pyramid is represented by the collection of fundamental (basic) norms, whose change is relatively slow as they are deeply rooted in social conscience; upper levels of the pyramid consist of functional norms affected by the external institutional environment [86].

The research emphasizes that intellectual entrepreneurship institutionalization, being a complex and durable process of forming the institutional system of innovative processes regulation, has its own peculiarities at each of the levels considered. It should also be mentioned that structural hierarchy of interaction and interinfluence relations is one of the characteristics of this process. The components of the intellectual entrepreneurship multilevel structure appear in the group of institutes that perform the functions inherent in them. At the same time, the levels of the intellectual entrepreneurship institutional structure operate interrelatedly within the frames of the hierarchical system of institutions. 


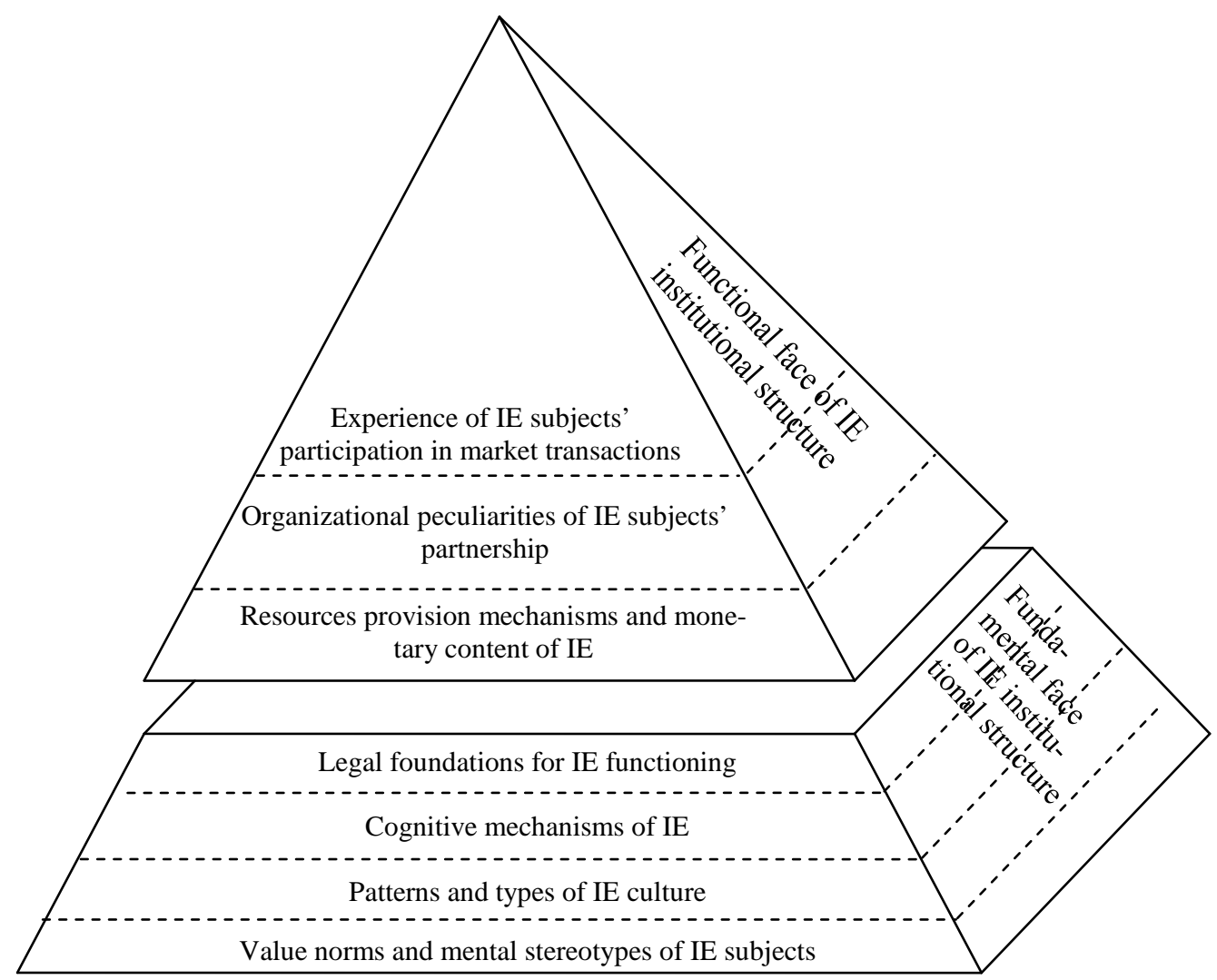

Fig. 11. Multilevel model of the intellectual entrepreneurship institutional structure

Nota bene: in Fig. 11 abbreviation IE is used for "intellectual entrepreneurship”.

To confirm that the interlevel approach fundamental principles have an effect on intellectual entrepreneurship functioning, it was shown that some basic economic institutes oriented mainly to one level have projections to other levels of the intellectual entrepreneurship institutional structure while other institutes greatly depend on the state of the external institutional environment. For instance, influence of such institutes as contraction, partnership, reliance is seen at all levels of institutional structuring but formation of value, cultural, cognitive and legal and regulatory levels of institutional hierarchy mainly results from synthetic influence on intellectual entrepreneurship of different exogenous factors and complex of the most important institutes of national economy (culture, state administration, taxation, corruption control, government support for innovation, etc.). The complete description of the model of the hierarchical institutional system is given in papers [26, p. 200-205; 86].

There are various parameters composing the hierarchy of elements of intellectual entrepreneurship so the question of the quality of institutional characteristics of the system under discussion arises. To solve this issue, a conceptual approach to evaluation of intellectual entrepreneurship institutional ineffectiveness was developed, which allows for detecting conditions and zones of qualitative deformations in functioning of the key formal and informal institutions. The results of empirical testing of the hypothesis about influence of exogenous and endogenous factors of the institutional environment on the intensity of intellectual entrepreneurship development is given in papers [26, p. 206218; 45].
Directions of overcoming institutional inefficiency, considering peculiarities of the institutional environment and the vector for evolution of intellectual entrepreneurship institutional forms, are combined in the model of strategic imperatives for reducing intellectual entrepreneurship disfunctions, developed for the Russian economy [44; 69; 85].

It is supposed that the study of intellectual entrepreneurship as a factor of competitive development of the Russian economy and regions under the conditions of urgent necessity for activation of the economic growth innovation component is rather promising; it is confirmed by the range of publications dedicated to this problem [54; 56; 94; 96; 107].

5. Study of the mechanism of regulating the system of regional goods markets on the basis of the hierarchical approach

One of the research areas within the framework of the academic school has become the study done by T.V. Karlina considering development of the regulation mechanism for the system of regional goods markets based on the hierarchical approach.

The hierarchical nature of economic systems can be clearly seen under the influence of modern globalization, which requires reconsidering of approaches to the governmental control of regional markets. In the context of international differentiation of labor, countries and regions are becoming more and more specialized, which leads, on the one hand, to strengthening of functional integrity and, on the other hand, to strengthening of their interdependence, as well as to activation of interlevel relations and strengthening of the expression of the economic system hierarchical 
structure. It entails alterations in economy regulation mechanisms towards modification of regulation methods and forms, their differentiation along the levels, subjects and objects of economic activity. Thus, it becomes essential to find ways to improve the mechanism of regulating regional goods markets system taking into account the polyhierarchical nature of economy, which requires studying market as a hierarchical system as well as researching mechanisms of its regulation in multilevel economy [26, p. 86-87].

The system of goods markets should be defined as a polyhierarchical one, which is a combination of various hierarchical structures and can be divided into subsystems in different ways according to the chosen structuring principle. In the course of the research conducted, three principles of hierarchical structuring goods markets systems have been identified; these de- fined its hierarchical analysis direction (Fig. 12):

- structural principle, allowing for taking into consideration the structure, internal and external relations of the market as a system consisting of several subsystems and included into greater social systems;

- spatial principle, allowing for taking into consideration the objective presence markets of different scales, which are included into one another and influence each other;

- organizational principle, allowing for taking into consideration the presence of multi-stage vertical regulation linkages (they form relations of submission between levels belonging to different subsystems), and a certain degree of self-regulation for the elements [28].

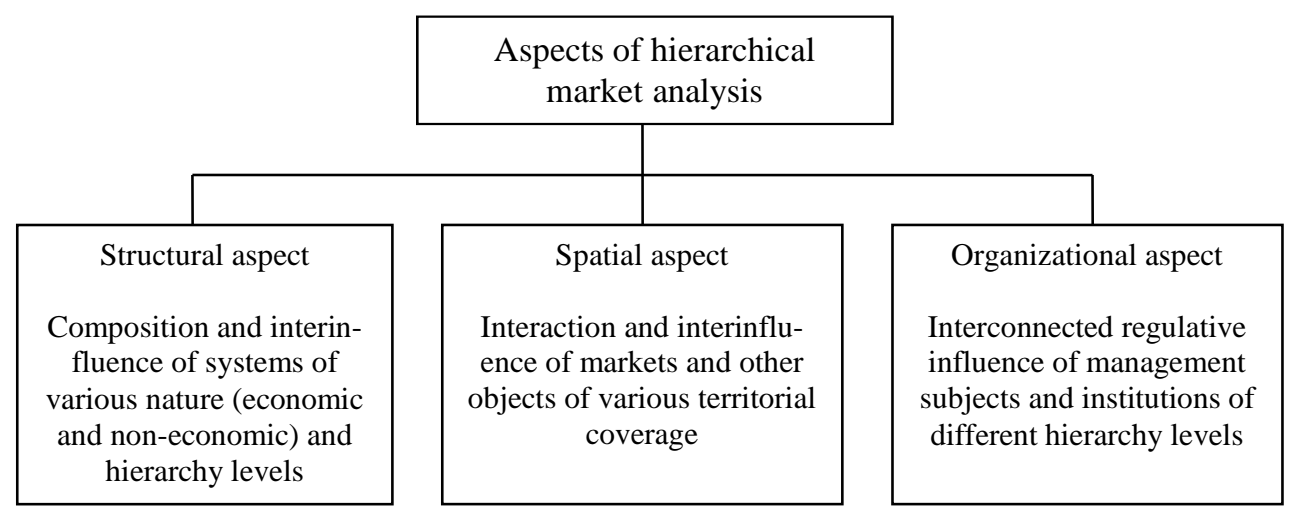

Fig. 12. Key aspects of hierarchical market analysis

The defined hierarchical linkages, their relations and dependence have an influence on the pace and direction of the development of the regional goods markets system as a whole and its constituents and this way affect the region's economy. It entails the necessity to develop an approach to the market hierarchical analysis which would allow for detecting:

- objects (factors) of different hierarchy levels in terms of structural and spatial aspects, those having the greatest influence on the given goods market of the region;

- regulation instruments allowing for reduction of a factor's negative influence or for creation of favorable conditions for positive influence on the given goods market development (Fig. 13).

The use of instruments of market regulation as part of a region's economic policy requires evaluation of the region's system of goods markets state. This evaluation would help to find regional markets which need urgent regulation and those dynamically developing under the existing level of the governmental influence. To achieve this goal, an evaluation technique was suggested in the course of the research which would allow for estimating the development of regional goods markets based on the microeconomic approach [32]. The application of this technique allows for detecting:

- constantly developing markets regulated effectively due to functioning of a market mechanism and current level of the governmental interference ;

- stable and relatively stable markets being characterized by not very advantageous dynamics and requiring either correction or strengthening of the government influence;

- unstable markets requiring extra, more complex analysis and attention from the government regulatory agencies [27; 33]. 


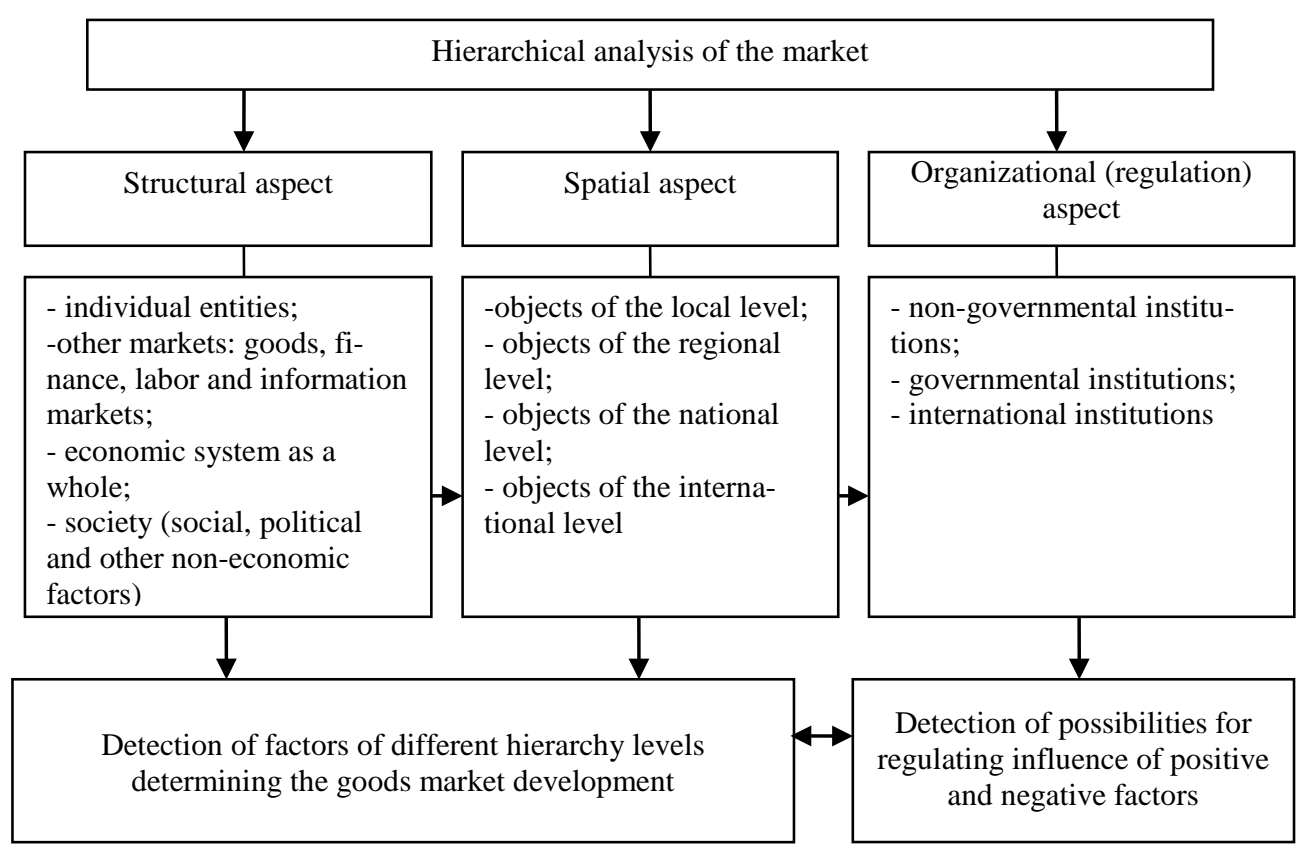

Fig. 13. Model of hierarchical analysis of the market [26, p. 99]

The key role in regulation of regional goods markets belongs to the regional level subjects; however, as it has been shown, in multihierarchical economy opportunities for their regulatory influence can be significantly limited by influence of other subjects and objects. To determine opportunities and restrictions of the local authorities' influence on a market, a technique for evaluating regional market openness degree was suggested, including regional market openness indicators in terms of demand and offer as well as evaluation matrix of regional markets openness degree and opportunities of their regulations by the instruments of the region's economic policy (Fig. 14).

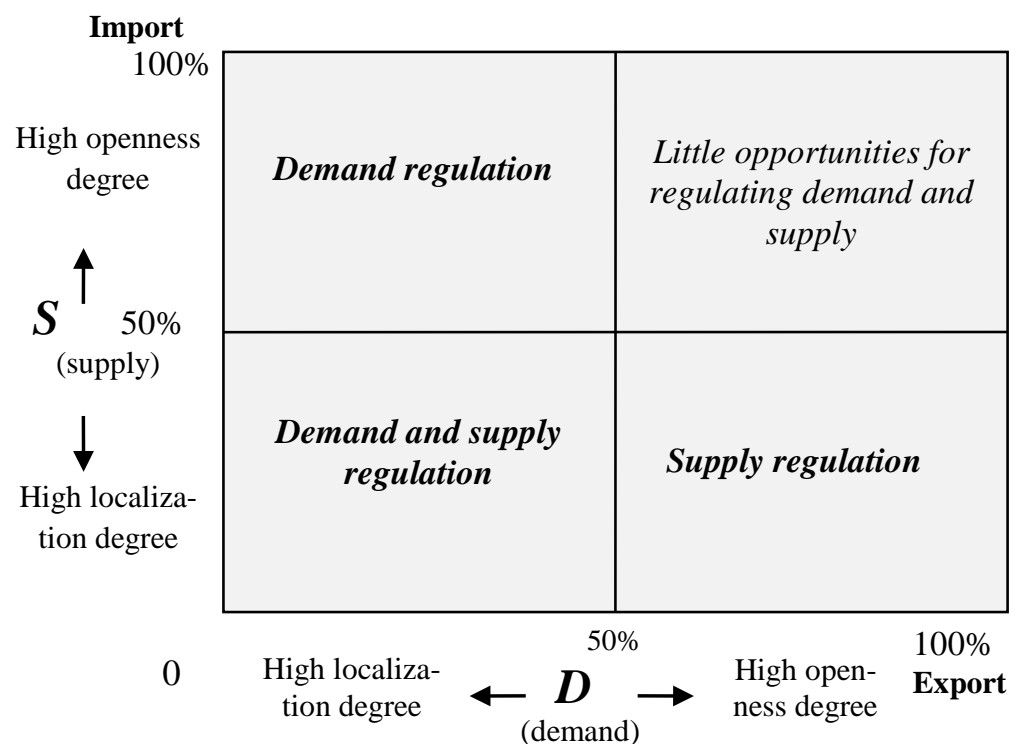

Fig. 14. Matrix of evaluation of regional markets' openness degree and opportunities for their regulation with the instruments of the region's economic policy [29]

The complex research into the processes of the region's goods market regulation in multi hierarchical economy on the basis of the technique suggested made it possible to present a model of hierarchical regulation of regional goods market [31], which would reflect elements of the multi hierarchical system under investigation and demonstrate that regulation of the market has to be performed with the account of

- intensity and direct influence of regulation entities of different hierarchical levels on it;

- intensity and indirect influence of various objects of different hierarchical levels on it (Fig. 15). 


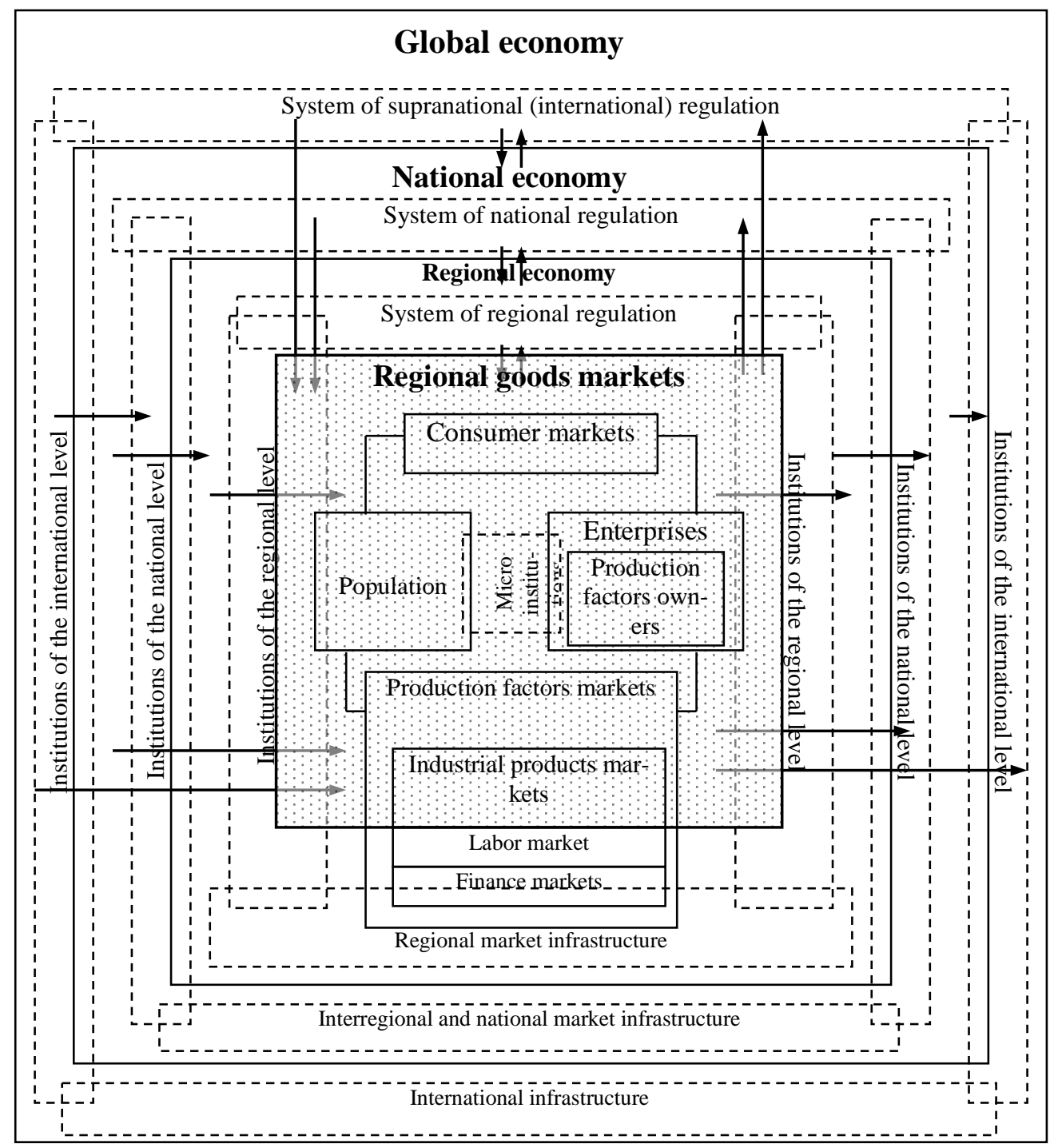

Fig. 15. Model of hierarchical regulation of regional goods markets

Thus, it has been shown that formation of an effective mechanism of the region's goods markets regulation requires application of the hierarchical approach, taking into consideration multi subjectivity of the regional economy regulation system.

One can state that development of the hierarchical approach is an attribute of the practice of government regulation of the Russian economy and that the conditions for implementation of the corresponding organizational innovations have already been formed.
The research conducted made it possible to define the principles for working out concepts and development programs for regional goods markets (or corresponding sections of strategies/programs of socio-economic development of the subject of the Russian Federation) [63] and also to develop a mechanism for hierarchical regulation of the system of regional goods markets [28]. The model of hierarchical regulation of the regional goods markets system and interlevel interaction mechanisms is presented in Fig. 16 [26]. 


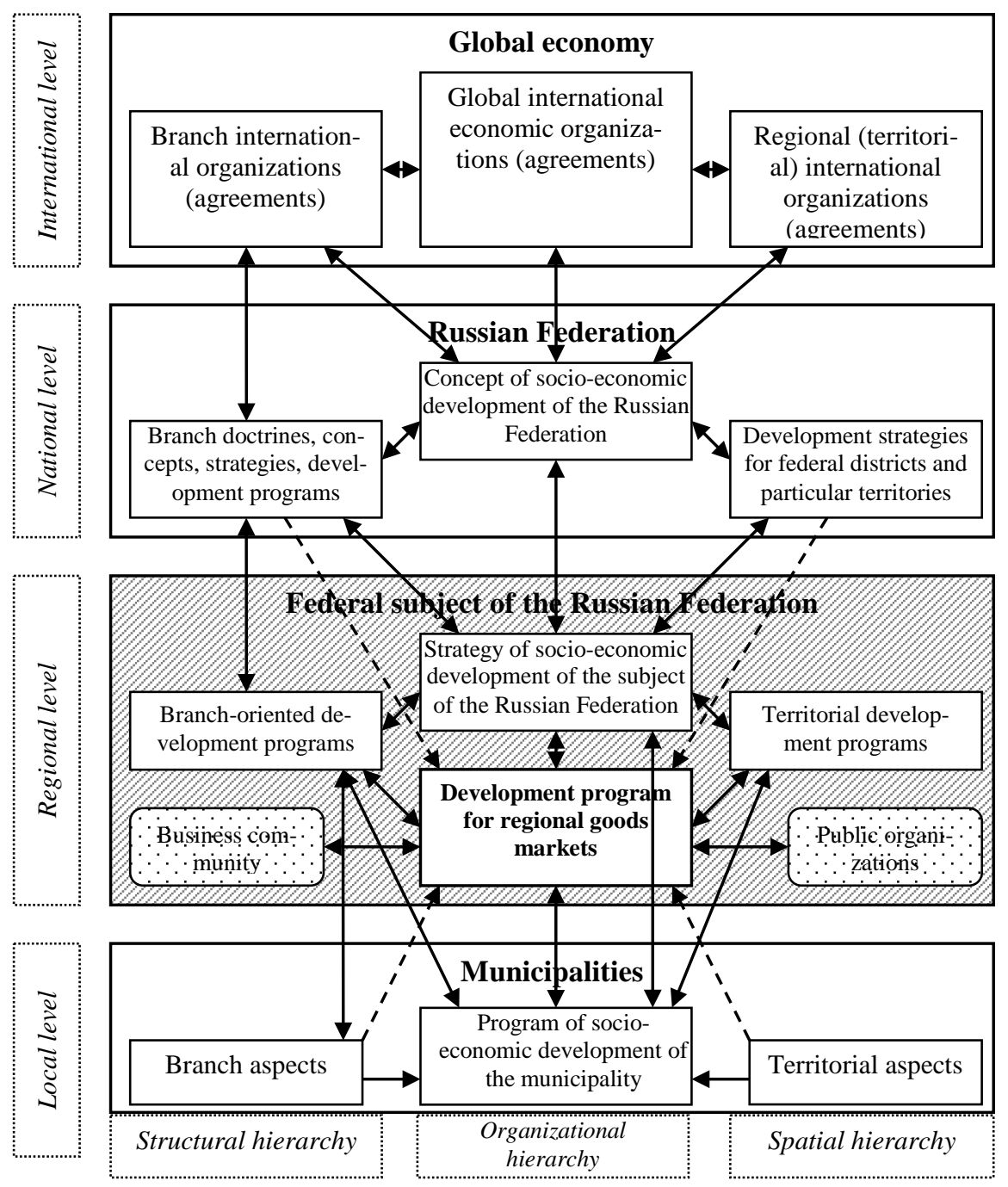

Fig. 16. Mechanism of hierarchical regulation of the regional goods markets system

When forming a region's economy regulation mechanism ,it is necessary to take into consideration the multilevel character of the regulation system, including not only state but other formal institutes (supranational and non-state) as well as informal institutes, whose influence on conduct of economic agents is quite significant and can dramatically alert the result of the authority's administrative effect. Besides, it has to be noted that any action triggered at one of the hierarchy levels spreads and influences the objects of all the levels and actions of subjects belonging to other hierarchy levels can significantly affect the state of regional economy. Successful implementation of the model of hierarchical regulation of the regional goods markets system can increase their functioning efficiency due to the synergy effect provided by coordination of actions of all the agents involved.

\section{Approaches and applications of} hierarchical and institutional analysis towards modeling various socio-economic systems

In studies [20; 72; 73] the possibility and necessity of application of the hierarchical approach to analysis of different relations has been justified; the above relations can occur between economic entities at local branch markets, e.g. a reinforced concrete products market and a housing construction market. It has also been justified that it is possible to influence strategic interaction and innovative development of entities of hierarchically connected goods markets via information asymmetry management. The detailed analysis of relations in the system "housing construction market - economy of the region" is presented in [25, p. 137-206; 79; 80; 81]. In these researches, on the basis of the synthesis of hierarchical, correlation and expert analyses, methods for integral evaluation of factor potential of a region's housing construction market have been developed. Multiplicative influence of the housing construction market on a region's socio-economic development has been shown. Horizontal and vertical disproportions of the housing construction market were revealed, which allowed its regulation directions and development to be defined along with specifying the purposes and functions of each entity of the market for making their interaction more effective.

Application of the hierarchical analysis instrumentarium for investigating local self-governance institutions providing interaction and agreement of economic entities' interests is considered in papers [23; 24; 74; 75]. The fundamental results of the researches are as follows:

- the concept of economic entities' interests harmonization has been formulated; this being based on the acceptance of municipal entities' integrating role and reflecting interrelation and interdependence of interests of entities of different levels of economy as a hierarchical system;

- the model of formation of institutional poten- 
tial of interlevel interests coordination has been developed; the model includes matrix representation of local authority institutions and quantitative evaluation of factors for economic entities' interests harmonization;

- the conditions for resolution of institutional inefficiency of the local self-government system have been identified; these are defined by the dominant role of economic entities' interests harmonization as a factor for reduction of transactional expenses in the system of hierarchical relations of economy.

The building of a multilevel model of credit market institutional culture is represented in studies [92; 105; 106]. This model enables us to accurately determine the reasons for institutional conflicts on the Russian credit market, among which are violation of the principle of integrity and sequence of the institutional structure levels altering. It has been found that the presence of time lag between the extension of credit and credit repayment moments gives rise to some uncertainty and asymmetric distribution of information between a credit grantor and credited party and provides a range of opportunities for conflicting behavior. Thus, the theoretical instrumentarium developed to analyze conflicting behavior of credit relations participants can provide the basis for the identification of the direction of national credit investment policy, determined by the role of the institutional structure of the credit market, which is considered as a factor of transaction expenses decline.

The analysis of administrative relations occurring during the process of a region's innovative system development with the use of the hierarchical analysis instrumentarium is presented in papers $[2 ; 3 ; 4 ; 5 ; 25$, p. 385-410]. The research resulted in a technique for identification of a region's type according to its innovative potential based on the analysis of the socio-economic and innovative environment interinfluence. The typology given helped to define priorities when choosing regional strategies in the process of a region's innovative system management.

Ideas introduced by Yu.K. Persky’s academic school are being actively developed nowadays in terms of theory, methodology and practice of regional economy's development. This work has a variety of practical applications, for instance, scientific support for a region's economic policy. These researches are conducted under the supervision of Doctor of Economic Sciences, Professor Tatiana V. Mirolyubova.

Among the most important studies stating theoretical, methodological and methodical fundamentals for government regulation of regional economic development, the following publications should be named: [59; $61 ; 62 ; 65]$.

Let us briefly set forth the main results of research into some essential theoretical applied problems of regional economic science development.

One of the most important problems in modern economics is development and justification of an effective model of state management of economy by means of the cluster approach.

The cluster approach is an effective tool for stimulating regional development and one of the means of structural changes as well as innovative and investment activity increase. Clusters having branch and polybranch characteristics can serve as key macro- and mesoeconomic units of territories' competitiveness. Thus, cluster analysis results provide scientific basis for development of a competitive structural policy, whose efforts, funding, and measures should be aimed at potentially competitive sectors and branches of regional economy.

The development and system justification of the principles of regional economy cluster structuring using its regional and innovative resources is given in the following papers $[57 ; 58 ; 60 ; 61]$. In particular, T.V. Mirolyubova in her research

- defines the principles and model of a region's economy cluster structure; these are based on identification and classification of regional economic clusters;

- justifies a set of concepts proving that clusterization has to be manageable, which would provide structural shifts in economy of the territory and transformation the type of economic growth based on export of raw materials into an innovative one;

- develops methodology for complex analysis of a region's economic development in terms of the cluster approach, which resulted in determination of major directions of socio-economic development of the region, the most important of which are: establishment of state mechanisms to support business and citizens; providing steady growth of the gross domestic product due to development of cluster economic structures; providing conditions for equal and free access to resources and consumers for entities of the market; creation of the infrastructure encouraging human potential development;

- works out a technique of conducting macroeconomic analysis of mesoeconomics (regional level) and a new model of state management of a region's economy development, which allows a cluster structure to be provided through mechanisms of various purpose-oriented programs implementation;

- defines variants of a territory's economic development scenarios and specifies methodology for planning activity of regional executive authorities, taking into consideration the necessity for formation of the economic cluster structure.

To develop a methodical approach [30; 39; 41; 42] to regional cluster analysis basic theoretical and methodological principles of cluster structuring were used ${ }^{1}$. The technique is a combination of quantitative and qualitative methods of clusters diagnostics and includes five steps:

1. Identification of clusters present in the region's economy;

2. Classification of regional clusters and their life cycle stages;

3. Establishment of market orientation of the clusters;

4. Evaluation and research of the dynamics of the clusters' qualitative features (size, weight and location coefficient);

5. Analysis of regional clusters spatial location (including cluster mapping) [65, p. 54-62].

The approach suggested takes into account the

\footnotetext{
${ }^{1}$ The research was supported by grant RGNF №11-12-59011 "Principles and mechanisms of formation and development of regional clusters” and conducted by T.V. Mirolyubova, T.V. Karlina, T.Yu. Kovalyova.
} 
multilevel nature of the cluster structure encompassing three major levels: a "cluster nucleus" (the first level), a group of companies surrounding the "cluster nucleus" (the second level) and serving companies forming cluster infrastructure and state authorities (the third level).

Elements in the cluster structure have horizontal and vertical ratios and linkages; there is competitiveness inside the cluster, on the one hand, and cooperation and collaboration, on the other. In this respect, interaction between the companies of the cluster nucleus and the organizations of the second and third levels takes place on the basis of value accumulation chains. Identification of the missing components of the chains helps to identify the types of economic activity having marketing potential for successful development and able to become competitive segments of a cluster chain.

The technique was tested on the economy of the Perm region. As a result, the following clusters were revealed:

1. The cluster of woodworking.

2. The cluster of wooden house-building.

3. The cluster of furniture production.

4. The cluster of paper production.

5. The cluster of oil processing.

6. The cluster of industrial and household chemical products.

7. The cluster of fertilizers.

8. The cluster of pharmacy.

9. The cluster of textile, clothes and accessories.

10. The cluster of food commodities.

11. The cluster of base metals primary treatment.

12. The cluster of mechanical engineering and metal-working industry.

13. The cluster of household appliances.

14. The cluster of electrical and office equipment.

15. The cluster of cable.

16. The cluster of aerospace engineering.

17. The cluster of instrument-making.

18. The cluster of building materials and construc-

tions.

19. The cluster of construction [63; 65, p. 63-77].

The research conducted led to the following conclusions:

- the clusters identified are characterized by different localizations in municipal entities due to the peculiarities of natural resources and industrial enterprises distribution. For instance, the clusters of woodworking and building materials cover the territory of the Perm region almost entirely while the clusters of aerospace engineering, of pharmacy and some others are concentrated mostly in the region's capital;

- many enterprises of the Perm region, trying to increase their competitive ability, tend to clustering and cooperation with large enterprises aiming at growing and intensive markets; doing so, they tend to meet the demand of those enterprises for the necessary products. The best example of such a structure is the oil extraction and processing sector, in which all the three levels of the cluster structure are presented;

- the industrial clusters identified in the region were formed due to three major competitive benefits, which are close location to the source of raw materials, high concentration of industrial enterprises within the region, a large number of qualified specialists. These re- gional competitive benefits form the conditions for perspective development of regional industrial clusters. At the same time, for development of the cluster enterprises, not only the enlisted above benefits inside the cluster are necessary but also favorable conditions of the region's business-environment. These conditions make the territory attractive for cluster companies development, let them achieve high working efficiency and innovative activity and are created primarily by governmental authorities of either federal or regional levels;

- an essential factor for competitive industrial clusters formation in the region's economy is advanced institutional environment, which contributes to the creation of the territory's competitive benefits and favorable factors for geographical concentration of enterprises, as well as combination of institutes of competitiveness and cooperation, formation of a strong "cluster nucleus" or a cluster leader. The above conclusion is confirmed by the results of economic analysis of interrelations between the quality of the region's economy institutional regime and major cluster parameters (weight and size) [43].

Orientation to this technique makes it possible to develop and justify the organizational and managerial mechanism of regional clusters development, whose special feature is the fact that entities of different levels participate in management processes and that harmonization of interests of the regional public authorities, a coordinating cluster organization and companies-participants of the cluster is provided.

Further studies of cluster organization of the region's economy have shown that the technique suggested is useful for identification and analysis of service industry clusters having similar three-level structure. For detecting potential clusters in educational space of the Perm region, T.Yu. Kovalyova and V.G. Baleyevskikh have developed a cluster analysis algorithm, whose step-by-step application resulted in detection of four potential clusters. These are clusters of pre-school education, school education, additional education for children, professional education and further training [46]. The hierarchical structure and modeling of relations with identification of cluster participants according to the levels they are at has been done for the professional education and further training cluster, which made it possible to define regional cluster policies on education in the Perm region [40; 47].

There is one more aspect which cannot be missed out in the given research review. It is the discussion on globalization and regionalization of the modern economy. Regionalization is considered as a system characteristics of the global economy and means strengthening of the role of separate territorial entities when forming an innovative economic model within both national and international economic space. Thus, the regional level is the one to play a key role in a competitive innovation system development.

This view of the problem above is presented in works by P.A. Sukhanova [102; 103; 104].The researcher gives conceptual and methodical fundamentals for the developing indicative evaluation of a regional innovative system in terms of the cluster approach for taking reasonable administrative decisions aimed at this system's advancement. The results and conclusions obtained in the course of the research are specified: 
- in the regional innovative system model, which determines elements of the region's innovative system and their relations with the account of basic conditions of regional economy's development as well as system elements of generation, transferring, and diffusion of new knowledge and technologies through interaction of science, authorities and business;

- in the approach to researching a regional innovative system based on individual indicators and dynamic approach, which differs from the existing practice;

- in the instrumentarium of the organizational economic mechanism for managing the regional innovative system development by the region's state power bodies; this instrumentarium takes into account the relations between elements of the regional innovative system providing generation, transferring, and diffusion of new knowledge and technologies.

It is necessary to emphasize that while elaborating the conception of identification and diagnostics of the regional economy's cluster potential, Perm scientists came to a conclusion that the problem of the territory's cluster development had been understudied. In current scientific literature, not enough attention is given to working out criteria, factors and types of efficiency of regional cluster spatial development under the conditions of the transfer to innovative economy.

Meanwhile, establishment of cluster economy as a regional development instrument is of integrating nature. Establishment of efficient cluster structures allows for provision of complex solution for the territory's development strategy, industrial and social policy aimed at creating a competitive economic regional complex, transfer to the innovative model of regional development, improvement of competitive conditions for entrepreneurial activity, increase of the region's educational and scientific level, infrastructure advancement, etc. In that regard there is a need for development of theoretical and applied provisions of the conception of efficiency of the region's economy cluster development ${ }^{2}$.

can be found

Scientific novelty of the problem set in this way

- in the development of conceptual and methodological approaches to the investigation of the problem of effectiveness of cluster economy functioning based on the interlevel analysis and institutional approach;

- in the development of methods and models of formation of efficient regional clusters, whose functioning would strengthen and enhance the territory's competitiveness and competitive benefits;

- in the development of mechanisms of cluster projects support by the state, in the selection of economic instruments and methods of regional cluster policy, considering relations between participants and their interests.

The following will become the elements of modeling cluster spatial development efficiency:

- criteria and factors of efficiency of clusters' creation, functioning and transformation;

\footnotetext{
${ }^{2}$ Research is supported by the grant RGNF №16-12-59011 «Efficiency of the region cluster spatial development in transition to innovation economy».
}

- criteria, methods and instruments of efficient state policy on supporting the region's cluster structures;

- directions of effective interaction between companies-participants of clusters and governmental authorities, scientific, educational, financial and other organizations of the region and parties interested in the long-term perspective.

Some other currently important issues of regional development are considered in articles by scientists and lecturers of the Faculty of Economics of Perm State University. These are:

- the problems of organization and improvement of regional monitoring of industrial enterprises of oil and gas industry in the region and their probable solutions [48; 50];

- improvement of the techniques of evaluating economic efficiency of tax advantages based on the gross regional product, tax interinfluence and modern instrumentarium of investment, aimed at improving regional governance as well as at increasing budget and commercial effectiveness [49; 51].

- development of an effective mechanism for managing the region's market infrastructure potential taking into account interregional economic relations as well as informational analysis of regional economy [21; 22];

- modeling of the process of management and implementation of effective international economic activity in the region based on the strategic approach and taking into account institutional conditions and innovative potential of the regional economy as elements providing formation of the region's competitive advantages at international goods and services markets and in the sphere of international economic activity on the whole [53; 56; 67; 68].

\section{Conclusion}

According to the authors, the provided review of theoretical, methodological and applied scientific achievements of the Perm academic school "Competitiveness and management of socio-economic systems development: synthesis of hierarchical and institutional modeling of socio-economic systems" cannot give a complete and comprehensive description of scientific achievements of all its followers in view of multifacetedness of the problems set. However, the authors hope that the material presented outlines the concept of interlevel analysis and modeling of hierarchical and institutional interaction of socio-economic systems as well as of the wide range of their applications in the study of regional specificity of economic processes, which makes difference between the research conducted by Perm scientists and those done by our colleagues.

\section{References}

1. Afonina A.G. The economic content and mechanism of cluster development management in the region's economy. Abstract of Cand. econ. sci. diss. Perm, 2012. 24 p. (In Russian).

2. Akhmetova M.I. Analysis of mechanisms of hierarchical interaction of innovation and investment 
companies. Proc. $1^{\text {st }}$ Rus. Sci. Symp. on regional economy. Ekaterinburg, Institute of Economics of the Ural Division of the RAS Publ., 2011, vol. 2, pp. 11-14. (In Russian).

3. Akhmetova M.I. Analysis of the mechanisms of interaction between the subjects of a venture investment system. Innovative development of Russian economy: institutional environment. Proc. $4^{\text {th }}$ Intern. Sci. Conf. Ed. by V.P. Kolesov, L.A. Tutova. Moscow, MAKS Press Publ., 2011, vol. 4, pp. 246-257. (In Russian).

4. Akhmetova M.I. Mechanisms of hierarchical interaction of research universities, innovation and investment companies in a venture business system. The financial and economic problems of the modern economy: collected articles. Perm, Perm National Research Politechnic Univ. Publ., 2012, pp. 5-21. (In Russian).

5. Akhmetova M.I., Persky Yu.K. Formation of the region's innovative system: hierarchical approach. The university and the real business, 2015, vol. 1, pp. 230-235. (In Russian).

6. Bazueva E.V. Determinants of the quality of the institutional environment (a case study of gender power institutions). Economic analysis: theory and practice, 2012, no. 9, pp. 17-29. (In Russian).

7. Bazueva E.V. Econometric analysis of the relationship between the performance of the national economy and gender inequality. Moscow University Economics Bulletin, 2013, no 2, pp. 71-84. (In Russian).

8. Bazueva E.V. Institutional analysis of the system of gender power. Economic analysis: theory and practice, 2011, no. 19, pp. 9-20. (In Russian).

9. Bazueva E.V. Institutional roles of economic agents in the system of using human capital in the Russian labor market. Vestnik of Astrakhan State Technical University. Series: Economics, 2015, no. 2, pp. 22-32. (In Russian).

10. Bazueva E.V. International experience of developing a system of gender power institutions of the egalitarian type. Social research, 2015, no. 5, pp. 102109. (In Russian).

11. Bazueva E.V. Methods of selecting an effective strategy for institutional changes (a case study of the system of gender power institutions). Proceedings of the Donetsk National Technical University. Series: Economics, 2014, no. 1, pp. 37-48. (In Russian).

12. Bazueva E.V. On the influence of institutions of gender power on the results of the modern economy's functioning. Perm University Herald. Economy, 2012, no. 2, pp. 75-90. (In Russian).

13. Bazueva E.V. The human capital of the Perm region: gender peculiarities of realization. Economy of the region, 2010, no. 2, pp. 60-71.

14. Bazueva E.V. The peculiarities of establishment of egalitarian gender power institutions in Poland: lessons for Russia. A person, community, management, 2014, no. 2, pp. 55-72. (In Russian).

15. Bazueva E.V. The system of gender power institutions of the egalitarian type in Russia: on the trajectory of development. Ars Administrandi, 2015, no. 2, pp. 16-35. (In Russian).

16. Bazueva E.V. Transformation of gender power disposition in modern families as a driving force of institutional changes. Economic and Social Changes: Facts, Trends, Forecast, 2014, no. 4 (34), pp. 148-164.

17. Bazueva E.V., Persky Yu.K. Gender economy as a hierarchical system. Journal of economic theory, 2011, no. 2, pp. 7-20. (In Russian).

18. Bazueva E.V., Persky Yu.K. On the Development of Methodology of Feministic Economics: Synthesis of Institutional Theory and Hierarchical Analysis. World Applied Sciences Journal, 2014, no. 30 (12), pp. 1776-1780.

19. Cherwitz A.R., Sullivan Ch.A. Intellectual Entrepreneurship. A vision for graduate education. Change. November/December 2002. Available at: https://webspace.utexas.edu/cherwitz/www/ie/articles.ht $\mathrm{ml}$ (accessed 28.09.2015).

20. Dmitriev D.V., Kataeva Yu.V. Information asymmetry in hierarchical analysis of the interaction between concrete products and housing construction. Industrial Economics, 2010, no. 3, pp. 72-76. (In Russian).

21. Dombrowski M.A. The main prospects for the development of interregional economic relations in the Perm region. International trade and trade policy, 2009, no. 10, pp. 26-32. (In Russian).

22. Dombrowski M.A., Butorina O.V. Information analysis of regional economic processes. Economy and Entrepreneurship, 2015, no. 4-1 (57-1), pp. 310314. (In Russian).

23. Dubrovskaya Yu.V. Analysis of institutional inefficiency of local self-governance based on the hierarchical approach. Problems of the modern economy, 2011, no. 2, pp. 68-71. (In Russian).

24. Dubrovskaya Yu.V., Persky Yu.K. Harmonization of interests of economic agents within the system of hierarchical relationships in the economy. Journal of Economic Theory, 2011, no. 1, pp. 24-37. (In Russian).

25. Hierarchical analysis of socio-economic systems: approaches, models, applications: monograph: in 2 parts. Ed. by Yu.K. Persky. Perm, Perm National Research Polytechnic Univ. Publ., 2011, Pt. I. 412 p. (In Russian).

26. Hierarchical analysis of socio-economic systems: approaches, models, applications: monograph: in 2 parts. Ed. by Yu.K. Persky. Perm, Perm National Research Polytechnic Univ. Publ., 2011, Pt. II. 322 p. (In Russian).

27. Karlina T.V. Assessment of the competitive environment in regional consumer markets for goods and services: microeconomic approach. A panorama of competition. Information analytical bulletin. Ekaterinburg, Institute of Economics of the Ural Division of the RAS Publ., 2008, no. 3, pp. 146-151. (In Russian).

28. Karlina T.V. Development of the mechanism of regulating the system of regional goods markets on the basis of the hierarchical approach. Cand. econ. sci. diss. Perm, 2010. 237 p. (In Russian).

29. Karlina T.V. Government regulation of regional goods markets on the basis of assessing the degree of their openness. Development of the mechanism of strategic crisis management of corporate entities and regional industrial policy: problems and innovations. Proc. All-Russian research and practice conf. (Perm, 12 Nov. 2009). Perm, 2009, pp. 158-162. (In Russian). 
30. Karlina T.V. Identification of regional economic clusters' nuclei on the basis of the structural changes analysis under the conditions of the economy developing in cycles. Perm University Herald. Economy, 2011, no. 4 (11), pp. 18-29. (In Russian).

31. Karlina T.V. Increasing of regional goods markets' efficiency. Economics and property management, 2009, no. 2, pp. 45-48. (In Russian).

32. Karlina T.V. Methods of assessing development of the regional goods markets system: microeconomic approach. Regional economy: theory and practice, 2010, no. 3 (138), pp. 50-60. (In Russian).

33. Karlina T.V. Research into regional goods markets for the purposes of the region's economic policy. Current issues of economic sciences. Proc. $4^{\text {th }}$ AllRussian research and practice conf.: in 3 parts. (Part 1). Novosibirsk, CRNS - SIB-PRINT Publ., 2009, pp. 209214. (In Russian).

34. Kleiner G.B. Evolution of institutional systems. Central Economics and Mathematics Institute RAS. Moscow, Nauka Publ., 2004. 240 p. (In Russian).

35. Knowledge management in innovative economy: Textbook. Ed. by B.Z. Milner. Moscow, Ekonomika Publ., 2009. 599 p. (In Russian).

36. Kolesnikov A.A. Synergetics and scientific cognition. Synergetics and problems of control theory. Moscow, FIZMATLIT Publ., 2004, pp. 379-398. (In Russian).

37. Komarov S., Persky Yu., Suzdaleva G. Hierarchical interaction of strategic and operational marketing as a factor of a company's competitive and innovative development. RISC: resources, information, supply, competition, 2012, no. 2, pp. 90-94. (In Russian).

38. Konstantinov G.N., Filonovich S.R. Intellectual entrepreneurship, or the principles of gaining a competitive advantage in the new economy. Harvard Business Review. Russia, 2005. Available at: www.hbrrussia.ru (accessed 16.06.2008). (In Russian).

39. Kovaleva T.Yu. Algorithm of identification and evaluation of regional clusters. Perm University Herald. Economy, 2011, no. 4, pp. 30-40. (In Russian).

40. Kovaleva T.Yu. Comparative analysis of interpretations and models of educational clusters formation. Bulletin of Ural Federal University. Series Economics and Management, 2014, no. 4, pp. 155-163. (In Russian).

41. Kovaleva T.Yu. Diagnosis of clusters as a benchmark for the state territorial development policy. Journal of Economic Theory, 2011, no. 4, pp. 89-95. (In Russian).

42. Kovaleva T.Yu. Identification of leading branches in the economy of Perm territory as potential clusters. Economy of the region, 2012, no. 1 (29), pp. 181-186.

43. Kovaleva T.Yu. Institutional environment as a basis for development of industrial clusters. Journal of Economic Theory, 2014, no. 3, pp. 129-135. (In Russian).

44. Kovaleva T.Yu. The evolution vector for the development of institutional forms of intellectual entrepreneurship in Russia's economy. Ivanovo State University Bulletin. Series “Economics”, 2012, no. 2, pp. 1319. (In Russian).
45. Kovaleva T.Yu. The problem of institutional inefficiencies in the development of intellectual entrepreneurship. Bulletin of Ural Federal University. Series Economics and Management, 2009, no. 4, pp. 26-36. (In Russian).

46. Kovaleva T.Yu., Baleevskih V.G. Identification of the Educational Clusters in the Regional Economy: Theory, Methodology and Research Results (A Case Study of Perm Krai). Journal of Econometrics and Financial Management, 2014, vol. 2, no. 4, pp. 153-162. doi: 10.12691/ijefm-2-4-7.

47. Kovaleva T.Yu., Baleevskikh V.G. Modeling of educational clusters in order to determine the state policies on territorial development (a case study of the Perm region). Ars Administrandi, 2015, no. 1, pp. 28-50. (In Russian).

48. Kutergina G.V. Monitoring of formation and development of territorial production cluster: the problem of information support. Innovative economy and industrial policy of the region (ECOPROM-2015). Proc. Int. research and practice conf. Ed. by A.V. Babkin. St. Petersburg, 2015, pp. 568-576. (In Russian).

49. Kutergina G.V. Problems of assessing fiscal investment efficiency in the region. Proc. Int. research and practice conf. Peter the Great Saint- Petersburg Polytechnic University, scientific and educational center "Innovative Economy of Industry" together with the Tallinn University of Technology, Estonian Entrepreneurship University of Applied Sciences (MAINOR), with the participation of the Central Economics and Mathematics Institute of the RAS, "St. Petersburg State Polytechnical University Journal”. Ed. by A.V. Babkin. St. Petersburg, 2014, pp. 392-395. (In Russian).

50. Kutergina G.V., Ivanova O.G. Oil and gas complexes and clusters: identification and monitoring of the region's economy. Perm University Herald. Economy, 2015, no. 2 (25), pp. 99-110. (In Russian).

51. Kutergina G.V., Mingazinova E.R. Procedures for assessing and monitoring tax incentives efficiency: approaches and problems. The bulletin of the Far Eastern Federal University. Economics and Management, 2014, no. 1 (69), pp. 84-99. (In Russian).

52. Kwiatkowski S. Intellectual entrepreneurship and sustainable economic development in the postsocialist countries of Europe. Problems of the theory and practice of management, 2002, no. 3, pp. 21-27. (In Russian).

53. Loseva E.Yu., Oborina E.D., Mingaleva Zh.A. The role of institutional factors in managing regional international economic activity. Perm University Herald. Economy, 2011, no. 1(8), pp. 55-61. (In Russian).

54. Luneva E.V., Dudurkhanov A.A. Intellectual entrepreneurship as a system factor of improvement in the quality of corporate knowledge. Transport business of Russia, 2011, no. 5, pp. 85-90. (In Russian).

55. Medvedeva L. Intellectual entrepreneurship, or the principles of gaining a competitive advantage in the new economy. Social Policy and Social Partnership, 2009, no. 8, pp. 55-57. (In Russian).

56. Mingaleva Zh.A., Loseva E.Yu., Oborina E.D. The socio-economic approach to studying international economic relations of a region. Economy of the region, 2011, no. 1(25), pp. 182-187. (In Russian). 
57. Mirolyubova T.V. Formation of a new model of managing a federal subject at the regional level: theoretical and methodological approach. Problems of Contemporary Science and Practice. Vernadsky University, 2008, no. 3 (13), pp. 207-213. (In Russian).

58. Mirolyubova T.V. Identification of a cluster's boundaries as the starting point for implementing the system of economy's state regulation at the regional level. Tomsk State University Journal, 2008, no. 314, pp. 141147. (In Russian).

59. Mirolyubova T.V. Management of regional economy: theoretical and applied approach. LAP LAMBERT Academic Publishing, 2011. 216 p. (In Russian).

60. Mirolyubova T.V. Theoretical and methodological aspects of indicative planning of socio-economic development at the level of the federal subject. Problems of theory and practice of management, 2008, no. 8, pp. 30-40. (In Russian).

61. Mirolyubova T.V. Theoretical and methodological aspects of state regulation of economy in a federal subject. Perm, Perm State Univ. Publ., 2008. 402 p. (In Russian).

62. Mirolyubova T.V., Afonina A.G. The economic content and mechanism of managing clusters in regional economy. Perm, Perm State Univ. Publ., 2012. 183 p. (In Russian).

63. Mirolyubova T.V., Karlina T.V. Formation of the mechanism of regional economy's hierarchical regulation. Economy and property management, 2010, no. 4, pp. 14-19. (In Russian).

64. Mirolyubova T.V., Karlina T.V., Kovaleva T.Yu. Identification of regional clusters (a case study of the Perm region). Problems of theory and practice of management, 2012, no. 6, pp. 8-19. (In Russian).

65. Mirolyubova T.V., Karlina T.V., Kovaleva T.Yu. Patterns and factors of formation and development of regional clusters. Perm, Perm State Univ. Publ., 2013. 280 p. (In Russian).

66. Nort D. Institutions, Institutional Change and Economic Performance. Transl. from Engl. by A.N. Nesterenko. Moscow, Fond ekonomicheskoy knigi «Nachala» Publ., 1997. 180 p. (In Russian).

67. Oborina E.D., Mingaleva Zh.A. Development of the strategy of a region's international economic activity in programs of economy's structural modernization. Perm University Herald. Economy, 2010, no. 1(4), pp. 61-66. (In Russian).

68. Oborina E.D., Mingaleva Zh.A. Management of international economic activities in the framework of structural modernization of a region's economy (a case study of the Perm region). St. Petersburg State Polytechnical University Journal, 2010, no. 1(92), pp. 82-86. (In Russian).

69. Persky Yu., Kovaleva T. Institutional guarantee of entrepreneurship subjects' interaction. Conference «Innovation management and corporate sustainability». Prague, 2014. Available at: http://imacs.vse.cz/pr oceedings-2014/ (accessed 01.01.2015).

70. Persky Yu.K. The competitive vector of structural transformation of economic systems: synthesis of the evolutionary, institutional and hierarchical approaches. Journal of Economic Theory, 2008, no. 4, pp. 29-40. (In Russian).
71. Persky Yu.K. Theoretical fundamentals of formation of hierarchical relationships within the system "economic entities - macroeconomic environment". Journal of Economic Theory, 2006, no. 4, pp. 34-51. (In Russian).

72. Persky Yu.K., Dmitriev D.V. Formation of the information-economic mechanism of managing the level of information asymmetry in the regional branch market. Bulletin of the South Ural State University. Series “Economics and Management", 2009, no. 29, pp. 66-74. (In Russian).

73. Persky Yu.K., Dmitriev D.V. Interaction and interdetermination of competition processes and information asymmetry on the regional trade market. Economy of the region, 2010, no. 1, pp. 182-187.

74. Persky Yu.K., Dubrovskaya Yu.V. Institutional support for harmonization of interests in the system of hierarchical relationships of economy. Perm University Herald. Economy, 2011, no. 1, pp. 24-36. (In Russian).

75. Persky Yu.K., Dubrovskaya Yu.V. Institutionalization of local self-governance as a factor of regional development: hierarchical approach. Perm University Herald. Economy, 2012, no. 3.1, pp. 27-34. (In Russian).

76. Persky Yu.K., Dubrovskaya Yu.V. Institutions of local self-governance as a factor in the harmonization of interests of economic entities. Perm, Perm National Research Polytechnic Univ. Publ., 2014. 200 p. (In Russian).

77. Persky Yu.K., Dubrovskaya Yu.V. Transaction costs in the system of harmonization of interests of economic entities belonging to different hierarchical levels. Izvestia of the USUE, 2011, no. 3 (35), pp. 38-44. (In Russian).

78. Persky Yu.K., Kataeva Yu.V. Formation of the institutional structure of the housing construction market in the region. Perm University Herald. Economy, 2009, no. 4, pp. 97-107. (In Russian).

79. Persky Yu.K., Kataeva Yu.V. Hierarchical interaction of subjects of the regional housing market. Economy of the region, 2008, annex to no. 2, pp. 231241. (In Russian).

80. Persky Yu.K., Kataeva Yu.V. Local housing markets in the region: the vector of competitive development. Perm, Perm State Univ. Publ., 2010. 168 p. (In Russian).

81. Persky Yu.K., Kataeva Yu.V. Modeling of interrelations among agents of the regional housing market. Economy of the region, 2009, no. 2 (18), pp. 153-160. (In Russian).

82. Persky Yu.K., Kostareva L.V. The company and the macroeconomic environment (the basics of mesoeconomics). Perm, 2000. 104 p. (In Russian).

83. Persky Yu.K., Kovaleva T.Yu. Institutions of intellectual entrepreneurship. Perm, Perm State Univ. Publ., 2011. 163 p. (In Russian).

84. Persky Yu.K., Kovaleva T.Yu. On the essential foundations of intellectual entrepreneurship. Journal of Economic Theory, 2009, no. 1, pp. 63-75. (In Russian).

85. Persky Yu.K., Kovaleva T.Yu. Strategic imperatives for overcoming institutional inefficiencies of intellectual entrepreneurship in the Russian economy. Perm University Herald. Economy, 2009, no. 3, pp. 6-15. 
(In Russian).

86. Persky Yu.K., Kovaleva T.Yu. The institutional system of intellectual entrepreneurship. Schumpeter readings, 2013, no. 1, pp. 60-65. (In Russian).

87. Persky Yu.K., Petrov V.P. On the identification of hierarchical levels of economic entities in institutional economy. Journal of Economic Theory, 2006, no. 1, pp. 51-64. (In Russian).

88. Persky Yu.K., Shults D.N. Development of ideas of the hierarchical organization of economy in the history of economic thought. Perm University Herald. Economy, 2013, no. 4 (19), pp. 13-19. (In Russian).

89. Persky Yu.K., Shults D.N. Hierarchical analysis of economy: methods and models. Ekaterinburg, Institute of Economics of the Ural Division of the RAS Publ., 2008. 203 p. (In Russian).

90. Persky Yu.K., Shults D.N. Interaction of micro- and macroeconomy: hierarchical approach. Ekaterinburg, Institute of Economics of the Ural Division of the RAS Publ., 2005. 192 p. (In Russian).

91. Persky Yu.K., Shults D.N. State regulation of economy as a hierarchical system. Journal of Economic Theory, 2005, no. 2, pp. 25-46. (In Russian).

92. Persky Yu.K., Tupitsyna M.N. Analysis of credit relations in Russia: institutional and evolutionary approach. Proc. $2^{\text {nd }}$ Int. research and practice conf. "Trends in the development of the global trade in the $21^{\text {st }}$ century". Perm, 2007, pp. 176-183. (In Russian).

93. Persky Yu.K., Zavyalov A.Yu. On the role of innovation susceptibility in managing innovation adaptation of a regional socio-economic system (a case study of the subjects of the Russian Federation). Ars Administrandi, 2014, no. 1, pp. 27-36. (In Russian).

94. Pogudaeva M.Yu., Zabelin Yu.I. Intellectual entrepreneurship as a factor in increasing the efficiency of knowledge management. Economic Journal, 2009, vol. 16, no. 2, pp. 151-157. (In Russian).

95. Polterovich V.M. Elements of the theory of reforms. Moscow, Ekonomika Publ., 2007. 447 p. (In Russian).

96. Salikhova Z.M. Intellectual entrepreneurship as a form of realization of intellectual capital. Economic analysis: theory and practice, 2014, no. 20 (371), pp. 4452. (In Russian).

97. Shults D.N. Hierarchical economy, its levels and methods of their analysis. Vestnik of the Orenburg State University. Economic, natural and technical sciences, 2006, no. 10 (60), pp. 210-216. (In Russian).

98. Shults D.N. Hierarchical economy: analysis of the levels and interlevel relations. Izvestia: Herzen University Journal of Humanities and Science, 2011, no. 130, pp. 73-79. (In Russian).

99. Shults D.N. Microeconomic funding of macroeconomics and Bohr's complementarity principle. Vestnik Instituta ekonomiki Rossijskoj akademii nauk, 2014, no. 2, pp. 157-165. (In Russian).

100. Shults D.N., Grebnev M.I. Statistical Approach to Aggregation of Production Functions. Applied Mathematical Sciences, 2015, vol. 9, no. 134, pp. 66696689.

101. Shults D.N., Grebnev M.I. The statistical method of production functions aggregation. Economics and Mathematical Methods, 2016, no.1. pp. 149-165. (In
Russian)

102. Sukhanova P.A. A model of the regional innovation system: national and foreign approaches. Perm University Herald. Economy, 2015, no. 4(27), pp. 92-102. (In Russian).

103. Sukhanova P.A. Current innovation infrastructure of Russian national research universities in the regional innovation system: problems and solutions. Current problems of science and education, 2013, no. 4, pp. 249-257. (In Russian).

104. Sukhanova P.A. Interconnectedness of the regional innovation system and the level of the region's competitiveness (a case study of the Volga Federal District). Perm University Herald. Economy, 2015, no. 2(25), pp. 120-126. (In Russian).

105. Tupitsyna M.N. Factor analysis of opportunistic behavior by borrowers in the credit market of the Russian Federation. Journal of Economic Theory, 2007, no. 3, pp. 175-179. (In Russian).

106. Tupitsyna M.N. Improvement of the mechanism of interaction between participants of the credit market as a factor of economic growth. Hierarchical relationships in economic systems: theoretical and applied aspects: collected articles. Perm, Perm State Univ. Publ., 2005, pp 120-130. (In Russian).

107. Vatutina L.A., Khomenko E.B. Intellectual entrepreneurship: actors, typology and infrastructure support. The global scientific potential, 2015, no. 2 (47), pp. 100-103. (In Russian).

108. Zhulanov E.E. Economic-mathematical modeling of reproductive interactions of territorial socioeconomic systems: monograph. Ed. by Yu.K. Persky. Perm, Perm National Research Polytechnic Univ. Publ., 2014. 564 p. (In Russian).

109. Zhulanov E.E. Management of regional socio-economic asymmetry as a factor of economic growth. Managing large systems. Moscow, Institute of Control Sciences of the RAS Publ., 2011, iss. 32, pp. 131154. (In Russian).

110. Zhulanov E.E. Modeling of the national socio-economic system development under the influence of the regulatory environment for international economic activity of regional industry. Economic Sciences and $\mathrm{Hu}-$ manities, 2014, no. 4 (267), pp. 95-104. (In Russian).

111. Zhulanov E.E. Stimulation of innovative activity of regional markets' participants as a factor of economic growth in the region. Journal of Economic Theory, 2007, no. 1, pp. 123-142. (In Russian).

112. Zhulanov E.E. Theoretical and methodological approach to measuring the results of the hierarchical management of regional socio-economic systems. Economy and Entrepreneurship, 2014, no. 2 (43), pp. 5359. (In Russian).

113. Zhulanov E.E., Persky Yu.K. Interaction of the state and the region's industrial complex: models of hierarchical analysis and control. Ekaterinburg, Institute of Economics of the RAS Publ., 2010. 357 p. (In Russian).

114. Zhulanov E.E., Persky Yu.K. Reproduction contour of a municipality as a management model. Ars Administrandi, 2013, no. 1, pp. 5-26. (In Russian).

The date of the manuscript receipt: 25.12.2015. 
КОНКУРЕНТОСПОСОБНОСТЬ И УПРАВЛЕНИЕ РАЗВИТИЕМ НАЦИОНАЛЬНОЙ И РЕГИОНАЛЬНОЙ

ЭКОНОМИКИ: СИНТЕЗ ИЕРАРХИЧЕСКОГО И ИНСТИТУЦИОНАЛЬНОГО АНАЛИЗА

Е.В. Базуева, канд. экон. наук, доцент кафедры мировой и региональной экономики, экономической теории Электронный адрес: bazueva.l@mail.ru

Пермский государственный национальный исследовательский университет, 614990, г. Пермь, ул. Букирева, 15

Е.Е. Жуланов, канд. экон. наук, доцент кафедры экономики и управления промышленным производством Электронный адрес: zeepstu@yandex.ru

Пермский национальный исследовательский политехнический университет, 614990, г. Пермь, Комсомольский пр-т, 29

T.В. Карлина, канд. экон. наук, доцент кафедры мировой и региональной экономики, экономической теории Электронный адрес: tkarlina@yandex.ru

Пермский государственный национальный исследовательский университет, 614990, г. Пермь, ул. Букирева, 15

Т.Ю. Ковалева, канд. экон. наук, доиент кафедры мировой и региональной экономики, экономической теории Электронный адрес: kovalevatu@yandex.ru

Пермский государственный национальный исследовательский университет, 614990, г. Пермь, ул. Букирева, 15

T.В. Миролюбова, докт. экон. наук, профессор, декан экономического факультета, зав. кафедрой мировой и региональной экономики, экономической теории

Электронный адрес: mirolubov@list.ru

Пермский государственный национальный исследовательский университет, 614990, г. Пермь, ул. Букирева, 15

Д.Н. Шульи, канд. экон. наук, дочент кафедры информаиионных систем и математических методов в экономике Электронный адрес: shultz@prognoz.ru

Пермский государственный национальный исследовательский университет, 614990, г. Пермь, ул. Букирева, 15

Дается обзор теоретико-методологических, методических и прикладных выводов и результатов, полученных в рамках научной школы «Конкурентоспособность и управление развитием социально-экономических систем: синтез иерархического и институционального моделирования социально- экономических систем», основателем которой является проф. Юрий Калманович Перский. Центральным звеном исследований, проведенных пермскими учеными-экономистами, выступает проблематика межуровневого анализа социально-экономических систем на основе иерархического и институционального подходов. Предлагаемый инструментарий аргументированно показывает значимость изучения иерархических и институциональных взаимосвязей, игнорируемых традиционной неоклассической теорией, и необходимость системного исследования проблемы конкурентоспособности и управления в аспектах экономической иерархии: нано-, мини-, микро-, мета-, мезо-, макро-, мегауровень. Ключевыми элементами, которым уделяется основное внимание в рамках исследований научной школы, являются целостная модель иерархической экономики с учетом межуровневого взаимодействия и институционального строения; моделирование прямых, обратных, вертикальных и горизонтальных взаимосвязей, их типология и оценка влияния на разных уровнях иерархии; совершенствование государственной экономической политики; вопросы асимметричности распределения и циркулирования информационных потоков, их оптимизация; проблема гармонизации интересов участников экономических отношений и др. Особо выделен региональный вектор исследований пермских ученых, посвященный разработке теории, методологии и практики развития экономики региона в целях совершенствования региональной экономической политики. В частности, приведены результаты идентификации и оценки кластеров в экономике региона, обоснована настоятельная необходимость формирования целостной модели кластерного пространственного развития территории, изложены направления выращивания конкурентоспособной инновационной системы в регионе, показаны возможности моделирования процессов стратегического управления и реализации эффективной внешнеэкономической деятельности и развития рыночной инфраструктуры региональной экономики. Следовательно, синтез иерархического и институционального анализа позволил выстроить методологический и методический фундамент исследования иерархически устроенных национальной и региональной экономик, отдельных предприятий, отраслей и промышленно-технологических комплексов, разработать модели товарных и ресурсных рынков, осуществить структуризацию и проектирование различных институциональных систем и социально-экономических процессов.

Ключевые слова: иерархический подход, институциональный подход, межуровневый анализ, институты, сочиильно-экономические системы, конкурентоспособность, управление, эффективность, национальная экономика, региональная экономика, инновации, кластер.

Please cite this article in English as:

Bazueva E.V., Zhulanov E.E., Karlina T.V., Kovaleva T.Yu., Mirolyubova T.V., Shults D.N. Competitiveness and management of the national and regional economy's development: synthesis of hierarchical and institutional analysis // Vestnik Permskogo universiteta. Seria Ekonomika = Perm University Herald. Economy. 2016. № 1(28). P. 41-67. 